\title{
On the Influence of the $\mathrm{C} 2-\mathrm{O} 2$ and $\mathrm{C} 3-\mathrm{O} 3$ Bonds in the 4,6-O- Benzylidene-Directed $\beta$-Mannopyranosylation and $\alpha$ - Glucopyranosylation
}

\author{
David Crich ${ }^{*}$ and Olga Vinogradova \\ Department of Chemistry, University of Illinois at Chicago, 845 West Taylor Street, Chicago, II \\ 60607-7061.
}

\begin{abstract}
The synthesis of 4,6- $O$-benzylidene protected 2-deoxy-arabino, 3-deoxy-arabino-, and 3-deoxy-ribothioglycosides is described and their glycosylation reactions, with activation by either 1benzenesulfinyl piperidine/trifluoromethansulfonic anhydride or diphenyl sulfoxide/ trifluoromethanesulfonic anhydride, studied. In contrast to the corresponding 4,6- $O$-benzylidene protected glucosyl and mannosyl donors, which are $\alpha$ - and $\beta$-selective, respectively, poor diastereoselectivity is observed in all cases. The reasons for this poor selectivity are discussed in terms of the interaction between the $\mathrm{C} 2-\mathrm{O} 2$ and $\mathrm{C} 3-\mathrm{O} 3$ bonds in the glucosyl and mannosyl donors and of the influence of this interaction on the ease of formation of the intermediate glycosyl oxacarbenium ions.
\end{abstract}

\section{Introduction}

One of the more intriguing aspects of the 4,6-O-benzylidene-directed $\beta$-mannopyranosylation reactions developed in this laboratory $1-6$ is the change in selectivity observed with the corresponding glucopyranosyl and galactopyranosyl donors, which are $\alpha$-selective. ${ }^{4,6-9}$ This contrast in selectivity, originally seen with donors $\mathbf{1}$ and 2,7 on activation with trifluoromethanesulfonic anhydride in the presence of a hindered non-nucleophilic base such as 2,4,6-tri-tert-butylpyrimidine (TTBP), ${ }^{10}$ and subsequently observed with donors $\mathbf{3}$ and $\mathbf{4}$, on activation with 1-benzenesulfinyl piperidine (BSP) and triflic anhydride, ${ }^{4}$ is reflected in the reduced $\beta$-selectivity seen on going from the 3,4- $O$-carbonate protected 6-deoxymanno (rhamno) donor 5 to the corresponding gluco donor $6 .{ }^{11}$ 

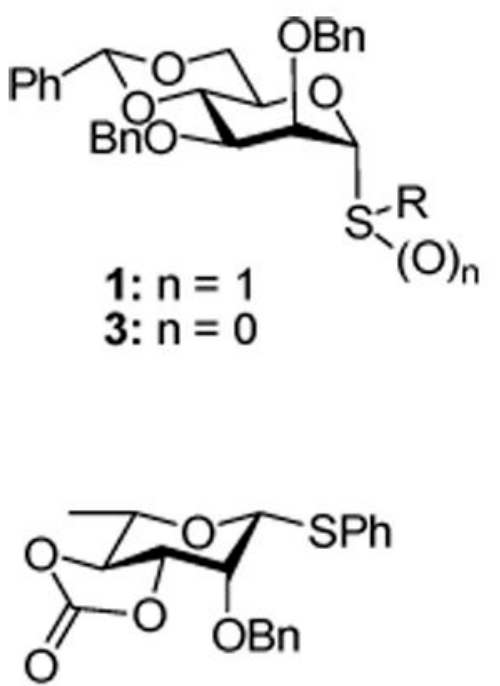

5

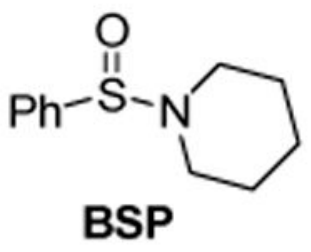

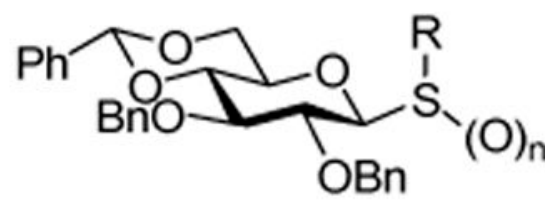

2: $\mathrm{n}=1$

4: $n=0$

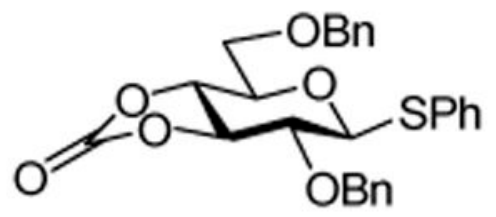

6<smiles>CC(C)(C)c1cc(Br)nc(C(C)(C)C)n1</smiles>

This difference in selectivity between the 4,6-O-benzylidene protected manno and glucopyranose series has been examined computationally by Nukuda and Whitfield and their coworkers, who viewed the problem in terms of the conformations of the intermediate oxacarbenium ions and of the protonated glycosides resulting from methanol attack on the oxacarbenium ions. ${ }^{12}$ However, it was recognized that the analysis was based on thermodynamic considerations and might not be relevant to kinetically determined stereoselectivity. It is well-known that the anomeric effect is higher in mannopyranosides than in glucopyranosides, leading to a greater thermodynamic preference for the $\alpha$-anomers in the mannose series, ${ }^{13}$ and it is evident that the glycosylation stereochemistries obtained with donors 1-4 at reaction temperatures from -78 to $-60{ }^{\circ} \mathrm{C}$ are kinetic in origin. Accordingly, while the geometries of the 4,6-O-benzylidene protected oxacarbenium ions computed by the Nukuda and Whitfield groups are taken into account in the discussion below, the rationale for glycosylation stereochemistry presented by these authors is not further considered. Differences in reactivity of mannopyranosyl and glucopyranosyl oxacarbenium ions have also been commented recently by Lucero and Woerpel, ${ }^{14}$ in the context of a broader investigation into the synthesis of C-glycosides and the influence of substituents on the stereoselectivity of oxacarbenium ion trapping. ${ }^{15}$ In the absence of a conformationally restricting group, such as the benzylidene acetal, these authors considered the tetra- $O$-benzylmannopyranosyl cation to exist predominantly in the ${ }^{3} \mathrm{H}_{4}$ conformer but to react via the less populated ${ }^{4} \mathrm{H}_{3}$ form, in a typical Curtin-Hammett kinetic scheme to afford the $\alpha$-C-glycosides in high yield. The $\alpha$ selective $\mathrm{C}$-glycosylation of the tetra- $O$-benzylglucopyranosyl cation was also considered to take place through the ${ }^{4} \mathrm{H}_{3}$ conformer. ${ }^{14}$ With the benzylidene acetal in place, and the ${ }^{3} \mathrm{H}_{4}$ conformer of the oxacarbenium ion excluded from consideration, the problem is simplified and only the ${ }^{3} H_{4}$ conformer need be considered along with the somewhat related $B_{2,5}$ and ${ }^{4} E$ 
conformers preferred by the benzylidene protected manno and glucopyranosyl cations according to the calculations of Nukuda, Whitfield, and their coworkers. ${ }^{12}$

We currently view the mechanism of the 4,6- $O$-benzylidene directed glycosylations, which are preformed operationally by pre-activation of the donor before addition of the acceptor, as proceeding through the intermediacy of a covalent glycosyl triflate 7 , which has been demonstrated spectroscopically to have the $\alpha$-configuration in both the manno and the gluco series. 7,16 This intermediate, which is formed rapidly and which is stable for many hours at low temperature in $\mathrm{CD}_{2} \mathrm{Cl}_{2}$, acts as a reservoir for a transient contact ion pair $\mathbf{8}$ (CIP) that is the true actual glycosylating species in the $\beta$-mannosylation reaction. ${ }^{17}$ This contact ion pair is in turn in equilibrium with a solvent separated ion pair (SSIP) 9, which we presume to be the source of the $\alpha$-glycosides (Scheme 1). The function of the benzylidene acetal is to shift the series of equilibria between $\mathbf{7}$ and the two ions as far as possible toward the covalent triflate 7, thereby minimizing the population of the SSIP 9 and, at least in the mannose series, the formation of $\alpha$-glycosides. The benzylidene acetal exerts its influence through a combination of torsional factors that come into play as the covalent triflate chair conformer flattens to the oxacarbenium ion in 8, 18,19 and by maintaining the C5-C6 bond in the most electron-

withdrawing $t g$ conformer. ${ }^{20}$ On this basis, the $\alpha$-selective glucosylations arise through the SSIP 9 and the problem is reduced to one of understanding the reasons for its greater population in the glucose series. There remains the alternative possibility that the $\alpha$-glucosides are formed via the intermediacy of a second contact ion pair, with the triflate counter ion shielding the $\beta$ face of the oxacarbenium ion, which would necessarily be in equilibrium with a covalent $\beta$ glycosyl triflate, much as envisaged by Lemieux in his halide-ion promoted $\alpha$-glucosylations. 21 While we can not exclude this mechanism conclusively, we consider it unlikely on the grounds that our NMR experiments provided no evidence for the existence of a $\beta$-glucosyl triflate. $^{7}$

We considered that the shift toward the SSIP 9 implied by the change from $\beta$ - to $\alpha$-selectivity observed on going from the manno to the gluco series might be due to greater repulsion between the O-2 substituent and the triflate counter ion in the CIP 8 in the gluco series, which would have the effect of facilitating SSIP formation (Figure 1).

Alternatively, we were intrigued by the notion that the $\mathrm{O} 2-\mathrm{C} 2-\mathrm{C} 3-\mathrm{O} 3$ torsional interaction plays a significant role in the observed differing selectivities between the manno and gluco series. Effectively, as the mannosyl triflate $\mathbf{1 0}$ collapses to the ion pair, in either the ${ }^{4} \mathrm{H}_{3}$ chair 11 or the $B_{2,5}$ conformer 12 preferred by Nukuda and Whitfield, ${ }^{12}$ the O2-C2-C3-O3 torsion angle increases (Table 1), whereas when the gluco triflate $\mathbf{1 3}$ is transformed into either the ${ }^{4} H_{3}$ chair 14 or the ${ }^{4} E$ conformer 15 favored by the computations ${ }^{12}$, the corresponding torsion angle is reduced (Table 2).

Examination of the change in the O2-C2-C1-O5 torsion angle with formation of the oxacarbenium ion is also instructive. In mannose (Table 1) there is an increase in this torsion angle on going from the covalent triflate 10 to the ${ }^{4} \mathrm{H}_{3}$ oxacarbenium ion 11, and maximization of this torsion angle in the $B_{2,5}$ conformer $\mathbf{1 2}$ of the oxacarbenium ion. On the other hand, in glucose the $\mathrm{O} 2-\mathrm{C} 2-\mathrm{C} 1-\mathrm{O} 5$ torsion angle, which begins at the maximum of $180^{\circ}$ in the covalent triflate 13, undergoes a significant reduction regardless of whether the oxacarbenium ion exists in the ${ }^{4} H_{3}$ or ${ }^{4} E$ conformations, $\mathbf{1 4}$ and $\mathbf{1 5}$, respectively (Table 2). By analogy with Bols' rationale for the benzylidene effect, ${ }^{20}$ it might be inferred that the higher O2-C2-C1-O5 torsion angle in the mannose oxacarbenium ions $\mathbf{1 2}$ and $\mathbf{1 3}$ maximizes the electron-withdrawing effect of the $\mathrm{C} 2-\mathrm{O} 2$ bond, as compared to that in the glucosyl oxacarbenium ions $\mathbf{1 4}$ and $\mathbf{1 5}$. This in turn would contribute toward a destabilization of the mannosyl oxacarbenium ions with respect to their glucosyl counterparts, which translates into a longer lived glucosyl oxacarbenium ion and a concomitant loss of selectivity. 
The effect of the O2-O3 interaction on the rate of acid catalyzed hydrolyzes of methyl glycopyranosides was one of several factors considered by Edward, ${ }^{23}$ Feather and Harris, ${ }^{24}$ and others ${ }^{25}$ in some of the classical studies in the area, but has subsequently been overlooked. With a view to probing these effects we have investigated the glycosylation stereoselectivity of a set of 4,6-O-benzylidene protected 2- and 3-deoxythioglycosides and describe here the results of our investigations.

\section{Results}

\section{Preparation of Donors}

The synthesis of the 2-deoxy donor $\mathbf{1 9}$ was straightforward and followed the protocol outlined in Scheme 2 starting from triacetyl glucal.

Obvious routes to the 3-deoxy donors beginning with the Barton deoxygenation of 1,2;5,6-di$O$-acetoneglucofuranose ${ }^{26}$ and proceeding through 3 -deoxy- $\beta$-D-ribo-hexopyranose and $1,2,4,6$-tetra- $O$-acetyl-3-deoxy- $\beta$-D-ribo-hexopyranose were not satisfactory owing to formation of furanose isomers in significant amounts. ${ }^{27}$ Eventually, a synthesis was devised in which 1,2;5,6-di- $O$-acetoneglucofuranose was converted to the known 3-deoxy-3-iodoallofuranose derivative 20, 28,29 which, on deprotection in acidic media and subsequent acetylation gave mainly the desired pyranose form. Radical deiodination then afforded $\mathbf{2 1}^{27}$ in good yield. Treatment with thiophenol and boron trifluoride afforded a 1:4 separable mixture of the anomeric thioglycosides $\mathbf{2 2}$ and $\mathbf{2 3}$, of which only the major $\beta$-isomer was processed through the subsequent routine steps of the synthesis to give the 3-deoxy ribo donor $\mathbf{2 5}$ (Scheme $3)$.

Adapting a classical scheme for the formation of $\beta$-mannopyranosides from the corresponding $\beta$-glucopyrnaosides, ${ }^{30-35}$ Dess-Martin oxidation ${ }^{36}$ of $\mathbf{2 4}$ gave the corresponding ketone, which was stereoselectively reduced with $\mathrm{L}$-selectride ${ }^{\circledR}$ to give the 3-deoxy arabino product 26. Benzylation then afforded the desired donor 27 (Scheme 4).

\section{Investigation of Key Intermediates}

Exploratory experiments conducted in $\mathrm{CD}_{2} \mathrm{Cl}_{2}$ by variable temperature ${ }^{1} \mathrm{H}-\mathrm{NMR}$ spectroscopy revealed the 2-deoxy donor 19 to be fully activated by the $\mathrm{BSP} / \mathrm{Tf}_{2} \mathrm{O}$ combination within minutes at $-60{ }^{\circ} \mathrm{C}$. However, only minor signals were observed in the region anticipated ${ }^{16}(\delta$ 6.0-6.3) for the anomeric signal of the putative glycosyl triflate intermediate 28. On warming to $-30{ }^{\circ} \mathrm{C}$, one major compound, the glycal $\mathbf{2 9}, 37$ was formed, as determined from key resonances at $\delta 6.38(\mathrm{dd}, J=6.0,1.2 \mathrm{~Hz})$ and $\delta 4.86(\mathrm{dd}, J=6.0,2.0 \mathrm{~Hz})$ indicative of the olefinic hydrogens, along with other unidentified byproducts. The result suggested the triflate 28 to be too unstable for the glycosylations in the 2-deoxy series. This behavior appears to be typical of the 2-deoxy series as a parallel experiment with donor $\mathbf{3 0}^{38}$ also failed to afford an observable glycosyl triflate but provided instead tribenzyl glucal 31 on warming to $-40{ }^{\circ} \mathrm{C}$. Activation of thioglycoside $\mathbf{1 9}$ with 2 equivalents of diphenyl sulfoxide 39,40 and 1.1 equivalents of triflic anhydride was also rapid and provided a putative intermediate glycosyl sulfonium ion 32, of the type observed by Gin in his studies on the activation of anomeric hemiacetals with diphenyl sulfoxide and triflic anhydride. ${ }^{41}$ On warming, decomposition of this intermediate was complete by $-50{ }^{\circ} \mathrm{C}$. In the 3-deoxy series, the chemistry reverted to more typical pattern observed previously in our laboratory $4,7,11,16,42$ with clean activation of both 25 and 27 by the BSP/Tf $2 \mathrm{O}$ couple at $-60{ }^{\circ} \mathrm{C}$ in $\mathrm{CD}_{2} \mathrm{Cl}_{2}$ and the formation of the putative glycosyl triflates $\mathbf{3 3}$ and $\mathbf{3 4}$, respectively, neither of which underwent decomposition until the temperature was raised to $-10^{\circ} \mathrm{C}$. 


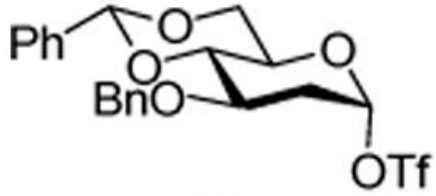

28

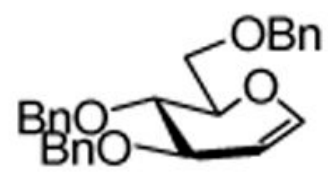

31

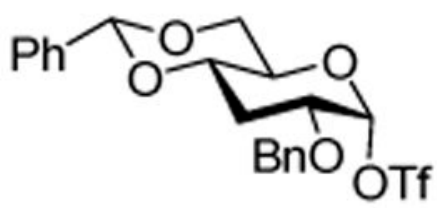

33

$$
\begin{aligned}
& \delta_{\mathrm{H} 1}=6.15(\mathrm{~d}, J=2.4 \mathrm{~Hz}), \\
& \text { decomp temp }=-20 \rightarrow-10{ }^{\circ} \mathrm{C}
\end{aligned}
$$

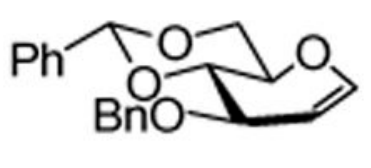

29

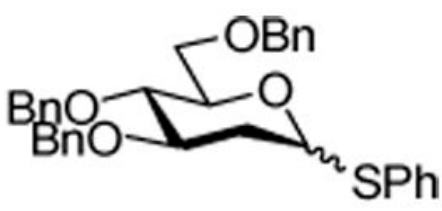

30

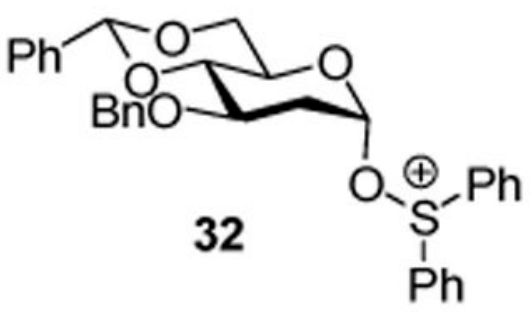

$\delta_{\mathrm{H} 1}=6.51(\mathrm{~d}, J=2.4 \mathrm{~Hz})$, decomp temp $=-50^{\circ} \mathrm{C}$

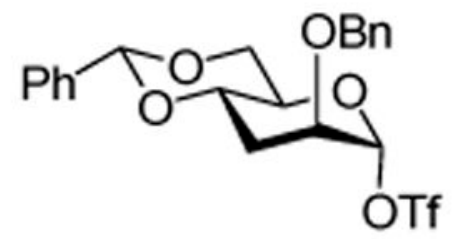

34

\section{Glycosylation Reactions}

In view of the variable temperature NMR experiments, couplings to the 2-deoxy donor 19 were conducted at $-60^{\circ} \mathrm{C}$ with preactivation by a combination of 2 equivalents of diphenyl sulfoxide and 1.1 equivalents of triflic anhydride in the presence of TTBP, before addition of the acceptor alcohol. Satisfactory yields were obtained in this manner but selectivities were poor, approaching a maximum of 4:1 $\beta: \alpha$ with a primary alcohol (Table 3 ). As determined by NMR spectroscopy of the crude reaction mixtures, comparable results were obtained when diphenyl sulfoxide was replaced by BSP, but isolated yields were reduced owing to difficulties in purification and are hence not reported.

Glycosylation reactions with the 3-deoxy donors $\mathbf{2 5}$ and $\mathbf{2 7}$ were conducted with preactivation by the $\mathrm{BSP} / \mathrm{Tf}_{2} \mathrm{O}$ couple in the presence of TTBP before addition of the acceptor, and are thought to proceed via the intermediacy of the glycosyl triflates 33 and 34 , respectively, on the basis of the variable temperature experiments. The results of these experiments, all of which proceeded with good yield but modest selectivity, are reported in Table 4 and Table 5 .

While the assignment of stereochemistry in the 2-deoxy series (Table 3) and in the 3-deoxy ribo series (Table 4) was straightforward based on the ${ }^{3} J_{\mathrm{H} 1, \mathrm{H} 2}$ coupling constants, that in the 3 -deoxy arabino series relies on the magnitude of the ${ }^{1} J_{\mathrm{C} 1, \mathrm{H} 1}$ coupling constants. ${ }^{43,44}$ 


\section{Discussion}

The lack of stereoselectivity observed with the 2-deoxy donor $\mathbf{1 9}$ (Table 3) is not surprising in view of the well-known difficulties in the stereoselective formation of 2-

deoxyglycopyranosidic linkages in general, ${ }^{45-47}$ and is somewhat anticipated on the basis of the variable temperature experiments and the manifest instability of the intermediates. These problems obviously arise from the greater lability of the 2-deoxy systems, which is the result of the absence of the electron-withdrawing $\mathrm{C} 2-\mathrm{O} 2$ bond and the greater facility of oxacarbenium ion formation that this affords. ${ }^{24,25,48-50}$ Accordingly, no further account is taken here of the results presented in Table 3. We do note, however, the reduced $\alpha$-selectivity seen with the donor 19 as compared to the high $\alpha$-selectivity seen by Kahne and coworkers with a series of 2,6-dideoxy glycosyl sulfoxides in the course of their syntheses of ciclamycin: 51,52 evidently the 4,6-O-benzylidene acetal is not without influence over the course of these reactions. In a similar vein, we note the $\beta$-selective glycosylations reported by Hashimoto on activation of the 2-deoxyglycosyl phosphite 49, and related phosphates, with trimethylsilyl triflate at $-94{ }^{\circ} \mathrm{C}$, which were considered to take place via intermediate glycosyl triflates, something that can not be excluded on the basis of the experiments presented here. ${ }^{53}$

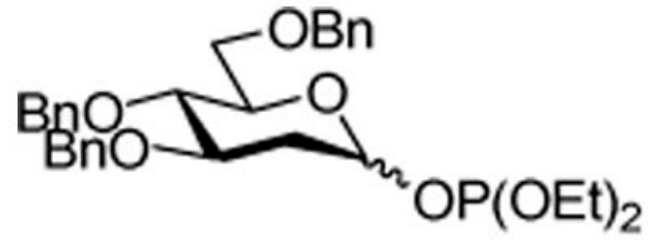

49

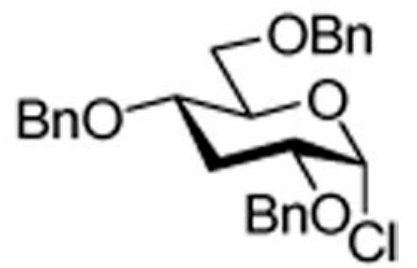

50

The results obtained with the 3-deoxy donors 25 and 27 (Table 4 and Table 5) are more germane to the question in hand. Various 3-deoxyglycopyranosyl donors have been described in the literature but, with rare exceptions, ${ }_{54}$ all carried ester protecting groups on $\mathrm{O} 2$ to direct the glycosylation stereochemistry $55-58$ and are not relevant to the present discussion. Interestingly, although the coupling was carried out under very different conditions to the ones employed here, the benzyl protected 3-deoxyglucosyl chloride $\mathbf{5 0}$ gave an approximately 1:1 mixture of two anomers on coupling to methyl 2,3,6-tri- $O$-benzyl- $\beta$-D-glucopyranoside by the Lemieux chloride ion-catalyzed protocol. 21,54 Classical work on the acid-catalyzed hydrolysis of simple glycopyranosides revealed that removal of the C3-O3 bond has only a relatively minor accelerating effect, ${ }^{23}-25,59$ as might also be inferred from more recent work on the disarming effect of ester protecting groups and their location on the pyranoside ring.

In the 3-deoxy ribo series (Table 4) there is a significant preference toward the formation of the $\beta$-glycosides, away from the $\alpha$-selectivity previously observed with the glucosyl donors 2 and 4. This does not accord with the hypothesis of Figure 1 in which repulsion between the 2-O-benzyl group and the triflate counter ion is responsible for a general loosening of the ion pair in the glucose series. Possibly, the move away from $\alpha$-selectivity with donor 25 is a reflection of a minor change in conformation of the oxacarbenium ion in the resulting CIP which facilitates $\beta$-face attack. As noted below, conformation effects have been shown to play a major role in the stereoselectivity of these glycosylation reactions.

In the 3-deoxy-arabino series (Table 5) there is a strong shift away from the high $\beta$-selectivity typically observed with donors $\mathbf{1}$ and $\mathbf{3}$. Obviously the absence of the electron-withdrawing C3-O3 bond can not be totally neglected here, but it seems apparent that the loss of the compression of the O2-C2-C3-O3 torsion angle seen in the mannose series (Table 1) on going 
from the covalent triflate to the oxacarbenium ion leads to a higher population of CIP and consequently of the SSIP with an overall reduction in $\beta$-stereoselectivity. In support of this argument, we recall the mannosyl donor $\mathbf{5 1}$ and its rhamnosyl counterparts $\mathbf{5 2}$ and $\mathbf{5 3}$, which adopt a half-chair conformation in which the $\mathrm{O} 2-\mathrm{C} 2-\mathrm{C} 3-\mathrm{O} 3$ torsion angle is $25-30^{\circ}$, as opposed to the $60^{\circ}$ in $\mathbf{1}$ and $\mathbf{3}$, and which are highly $\alpha$-selective in homogeneous glycosylation reactions: 60-62 subtle conformational effects play a major role in these glycosylation reactions, even to the point of overriding powerful electronic effects.

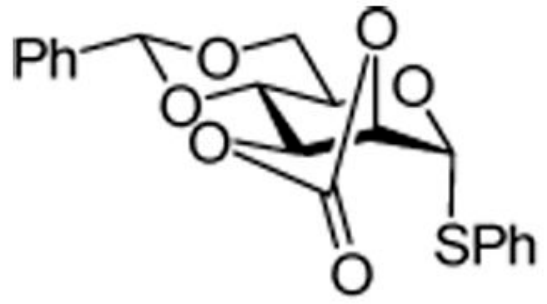

51

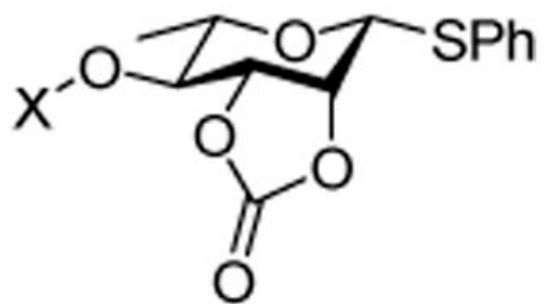

52: $\mathrm{X}=\mathrm{Bn}$

53: $X=A C$

Finally, we return to the possibility of the formation of the $\alpha$-glucosides via the intermediacy of covalent $\beta$-glucosyl triflate and an associated transient $\beta$-face contact ion pair. While this mechanism can not be ruled out as a contributing factor to the overall $\alpha$-selectivity seen in the glucose series, ${ }^{4,6-9}$ the poor selectivity seen with the 3-deoxy donors 25 and $\mathbf{2 7}$, irrespective of the configuration at $\mathrm{C} 2$, suggests that it is not a major pathway.

\section{Experimental Section}

General coupling protocol for S-Phenyl 3-O-benzyl-4,6-O-benzylidene-2-deoxy- $\beta$-o-arabinothiohexopyranoside (19) using $\mathrm{Ph}_{2} \mathrm{SO}$ (method A)

To a stirred solution of 19 (100 mg, $0.23 \mathrm{mmol})$ in $\mathrm{CH}_{2} \mathrm{Cl}_{2}(6 \mathrm{~mL})$ containing $\mathrm{Ph}_{2} \mathrm{SO}(93 \mathrm{mg}$, $0.46 \mathrm{mmol})$, TTBP (114 mg, $0.46 \mathrm{mmol})$, and activated $3 \AA$ powdered molecular sieves, $\mathrm{Tf}_{2} \mathrm{O}(42.6 \mu \mathrm{L}, 0.25 \mathrm{mmol})$ was added at $-60{ }^{\circ} \mathrm{C}$ under argon atmosphere. After 5 minutes, a solution of acceptor $(0.28 \mathrm{mmol})$ in $\mathrm{CH}_{2} \mathrm{Cl}_{2}(2.4 \mathrm{~mL})$ was added and the reaction mixture was stirred for an additional $2 \mathrm{~min}$ at $-60{ }^{\circ} \mathrm{C}$, then warmed to room temperature, filtered, washed (saturated aqueous $\mathrm{NaHCO}_{3}$, brine), and dried $\left(\mathrm{Na}_{2} \mathrm{SO}_{4}\right)$. The solvent was removed under reduced pressure. The crude was filtered through a pad of silica gel (with ethyl acetate as an eluent) and chromatographed using $\mathrm{SiO}_{2}$.

\section{General coupling protocol for S-Phenyl 2-O-benzyl-4,6-O-benzylidene-3-deoxy- $\beta$-о-ribo- thiohexopyranoside (25) and S-Phenyl 2-O-benzyl-4,6-O-benzylidene-3-deoxy- $\beta$-o-arabino- thiohexopyranoside (27) using BSP (method B)}

To a stirred solution of $\mathbf{2 5}$ or 27 (50 mg, $0.12 \mathrm{mmol}$ ) in $\mathrm{CH}_{2} \mathrm{Cl}_{2}(3 \mathrm{~mL})$ containing BSP (24 $\mathrm{mg}, 0.12 \mathrm{mmol})$, TTBP (57 mg, $0.23 \mathrm{mmol})$, and activated $3 \AA$ powdered molecular sieves, $\mathrm{Tf}_{2} \mathrm{O}(21.3 \mu \mathrm{L}, 0.13 \mathrm{mmol})$ was added at $-60{ }^{\circ} \mathrm{C}$ under argon atmosphere. After 5 minutes, a solution of acceptor $(0.14 \mathrm{mmol})$ in $\mathrm{CH}_{2} \mathrm{Cl}_{2}(1.2 \mathrm{~mL})$ was added and the reaction mixture was stirred for an additional $2 \mathrm{~min}$ at $-60^{\circ} \mathrm{C}$, then warmed to room temperature, filtered, washed (saturated aqueous $\mathrm{NaHCO}_{3}$, brine), and dried $\left(\mathrm{Na}_{2} \mathrm{SO}_{4}\right)$. The solvent was removed under reduced pressure. The crude was filtered through a pad of silica gel (with ethyl acetate as an eluent) and chromatographed using $\mathrm{SiO}_{2}$. 
Methyl 4-O-(3'-O-benzyl-4',6'-O-benzylidene-2'-deoxy-a-o-arabino-thiohexopyranosyl)-2,3O-isopropylidene- $\alpha$-L-rhamnoside (39 $\alpha$ ) and Methyl 4-O-(3'-O-benzyl-4',6'-O-benzylidene-2'deoxy- $\beta$-o-arabino-thiohexopyranosyl)-2,3-O-isopropylidene- $\alpha$-L-rhamnoside (39 $\beta$ )

Prepared by method A, purified by means of radial chromatography, eluting consecutive plates with haxanes to 1:9 diethyl ether:hexanes, and then with hexanes to 1:19 ethyl acetate:hexanes. Combined yield $94 \mathrm{mg}(75 \%, 1: 1.5 \alpha / \beta) .39 \alpha .[\alpha]^{24}{ }_{\mathrm{D}}+50.0\left(c 0.53, \mathrm{CHCl}_{3}\right) ;{ }^{1} \mathrm{H}$ NMR $(500$ $\left.\mathrm{MHz}, \mathrm{CDCl}_{3}\right) \delta: 7.52-7.57(\mathrm{~m}, 2 \mathrm{H}), 7.27-7.43(\mathrm{~m}, 8 \mathrm{H}), 5.64(\mathrm{~s}, 1 \mathrm{H}), 5.00(\mathrm{~d}, J=3.5 \mathrm{~Hz}$, $1 \mathrm{H}), 4.87(\mathrm{~d}, J=11.9 \mathrm{~Hz}, 1 \mathrm{H}), 4.86(\mathrm{~s}, 1 \mathrm{H}), 4.70(\mathrm{~d}, J=11.9 \mathrm{~Hz}, 1 \mathrm{H}), 4.29(\mathrm{dd}, J=10.0,5.0$ $\mathrm{Hz}, 1 \mathrm{H}), 4.07-4.15(\mathrm{~m}, 3 \mathrm{H}), 4.03(\mathrm{ddd}, J=11.2,9.1,5.1 \mathrm{~Hz}, 1 \mathrm{H}), 3.75(\mathrm{t}, J=10.1 \mathrm{~Hz}, 1 \mathrm{H})$, $3.71(\mathrm{t}, J=9.4 \mathrm{~Hz}, 1 \mathrm{H}), 3.65(\mathrm{dd}, J=10.0,6.3 \mathrm{~Hz}, 1 \mathrm{H}), 3.37(\mathrm{~s}, 3 \mathrm{H}), 3.31-3.36(\mathrm{~m}, 1 \mathrm{H}), 2.27$ $(\mathrm{dd}, J=13.2,5.1 \mathrm{~Hz}, 1 \mathrm{H}), 1.82(\mathrm{ddd}, J=13.3,11.2,3.9 \mathrm{~Hz}, 1 \mathrm{H}), 1.52(\mathrm{~s}, 3 \mathrm{H}), 1.34(\mathrm{~s}, 3 \mathrm{H})$, $1.26(\mathrm{~d}, J=6.4 \mathrm{~Hz}, 3 \mathrm{H}) ;{ }^{13} \mathrm{C} \mathrm{NMR}\left(125 \mathrm{MHz}, \mathrm{CDCl}_{3}\right) \delta: 138.7,137.7,128.8,128.4,128.2$, 127.7, 127.6, 126.1 109.1, 101.3, 98.6, 98.0, 84.0, 80.3, 76.9, 75.9, 73.0, 72.8, 69.1, 64.8, 63.0, 54.8, 36.6, 28.2, 26.4, 17.5; ESIHRMS Calcd for $\mathrm{C}_{30} \mathrm{H}_{38} \mathrm{NaO}_{9}[\mathrm{M}+\mathrm{Na}]^{+}:$565.2414. Found 565.2409. 39ק. White solid. M.p. $108-111^{\circ} \mathrm{C}$; $[\alpha]^{24}{ }_{\mathrm{D}}-40.3\left(\mathrm{c} \mathrm{0.31}, \mathrm{CHCl}_{3}\right) ;{ }^{1} \mathrm{H}$ NMR $(500$ $\left.\mathrm{MHz}, \mathrm{CDCl}_{3}\right) \delta: 7.49-7.54(\mathrm{~m}, 2 \mathrm{H}), 7.27-7.42(\mathrm{~m}, 8 \mathrm{H}), 5.61(\mathrm{~s}, 1 \mathrm{H}), 5.04(\mathrm{dd}, J=9.9,2.0$ $\mathrm{Hz}, 1 \mathrm{H}), 4.86(\mathrm{~s}, 1 \mathrm{H}), 4.81(\mathrm{~d}, J=12.1 \mathrm{~Hz}, 1 \mathrm{H}), 4.72(\mathrm{~d}, J=12.3 \mathrm{~Hz}, 1 \mathrm{H}), 4.28(\mathrm{dd}, J=10.5$, $5.0 \mathrm{~Hz}, 1 \mathrm{H}), 4.13-4.18(\mathrm{~m}, 1 \mathrm{H}), 4.09(\mathrm{~d}, J=5.5 \mathrm{~Hz}, 1 \mathrm{H}), 3.83(\mathrm{t}, J=10.3 \mathrm{~Hz}, 1 \mathrm{H}), 3.77$ (ddd, $J=11.2,9.0,5.1 \mathrm{~Hz}, 1 \mathrm{H}), 3.58-3.70(\mathrm{~m}, 3 \mathrm{H}), 3.37(\mathrm{~s}, 3 \mathrm{H}), 3.30-3.36(\mathrm{~m}, 1 \mathrm{H}), 2.36(\mathrm{ddd}$, $J=12.9,5.1,2.1 \mathrm{~Hz}, 1 \mathrm{H}), 1.65(\mathrm{ddd}, J=12.8,11.2,9.9 \mathrm{~Hz}, 1 \mathrm{H}), 1.51(\mathrm{~s}, 3 \mathrm{H}), 1.35(\mathrm{~s}, 3 \mathrm{H})$, $1.28(\mathrm{~d}, J=5.9 \mathrm{~Hz}, 3 \mathrm{H}) ;{ }^{13} \mathrm{C} \mathrm{NMR}\left(125 \mathrm{MHz}, \mathrm{CDCl}_{3}\right) \delta: 138.5,137.6,128.9,128.4,128.2$, 127.7, 127.6, 126.1, 109.3, 101.3, 98.7, 97.9, 83.2, 78.5, 77.8, 76.1, 74.6, 72.4, 69.0, 66.6, 64.1, 54.8, 37.8, 27.9, 26.4, 17.5; ESIHRMS Calcd for $\mathrm{C}_{30} \mathrm{H}_{38} \mathrm{NaO}_{9}[\mathrm{M}+\mathrm{Na}]^{+}:$565.2414. Found 565.2411 .

\section{3-O-(3'-O-benzyl-4',6'-O-benzylidene-2'-deoxy- $\alpha$-o-arabino-thiohexopyranosyl)-1,2:5,6-di-O- isopropylidene- $\alpha$-o-glucose (40 $\alpha$ ) and 3-O-(3'-O-benzyl-4',6'-O-benzylidene-2'-deoxy- $\beta$-o- arabino-thiohexopyranosyl)-1,2:5,6-di- $O$-isopropylidene- $\alpha$-o-glucose (40 $\beta$ )}

Prepared by method A, purified by means of radial chromatography, eluting consecutive plates with hexanes to 1:9 ethyl acetate:hexanes, and then with 7:13 or 1:4 diethyl ether:hexanes for $\mathbf{4 0} \alpha$ and $\mathbf{4 0 \beta}$, respectively. $40 \alpha$ yield $39 \mathrm{mg}(29 \%)$, $\mathbf{4 0 \beta}$ yield $62 \mathrm{mg}(46 \%)$. 40 $\alpha .[\alpha]^{24}{ }_{\mathrm{D}}+38.4$ (c $\left.0.25, \mathrm{CHCl}_{3}\right) ;{ }^{1} \mathrm{H}$ NMR $\left(500 \mathrm{MHz}, \mathrm{CDCl}_{3}\right) \delta: 7.50-7.57(\mathrm{~m}, 2 \mathrm{H}), 7.28-7.45(\mathrm{~m}, 8 \mathrm{H})$, $5.89(\mathrm{~d}, J=3.7 \mathrm{~Hz}, 1 \mathrm{H}), 5.66(\mathrm{~s}, 1 \mathrm{H}), 5.21(\mathrm{~d}, J=3.7 \mathrm{~Hz}, 1 \mathrm{H}), 4.87(\mathrm{~d}, J=11.7 \mathrm{~Hz}, 1 \mathrm{H}), 4.69$ $(\mathrm{d}, J=12.5 \mathrm{~Hz}, 1 \mathrm{H}), 4.56(\mathrm{~d}, J=3.7 \mathrm{~Hz}, 1 \mathrm{H}), 4.33(\mathrm{dd}, J=9.5,4.4 \mathrm{~Hz}, 1 \mathrm{H}), 4.24(\mathrm{~d}, J=2.9$ $\mathrm{Hz}, 1 \mathrm{H}), 4.09-4.18(\mathrm{~m}, 2 \mathrm{H}), 3.96-4.09(\mathrm{~m}, 3 \mathrm{H}), 3.78-3.90(\mathrm{~m}, 2 \mathrm{H}), 3.73(\mathrm{t}, J=8.8 \mathrm{~Hz}$, $1 \mathrm{H}), 2.29(\mathrm{dd}, J=13.2,5.1 \mathrm{~Hz}, 1 \mathrm{H}), 1.78-1.86(\mathrm{~m}, 1 \mathrm{H}), 1.50(\mathrm{~s}, 3 \mathrm{H}), 1.41(\mathrm{~s}, 3 \mathrm{H}), 1.33(\mathrm{~s}$, $3 \mathrm{H}), 1.32(\mathrm{~s}, 3 \mathrm{H}) ;{ }^{13} \mathrm{C}$ NMR $\left(125 \mathrm{MHz}, \mathrm{CDCl}_{3}\right) \delta$ : 138.6, 137.4, 129.0, 128.4, 128.3, 127.6, 126.0, 112.1, 109.3, 105.3, 101.3, 99.2, 84.1, 83.8, 81.4, 80.2, 73.1, 72.6, 72.4, 69.0, 67.9, 63.9, 36.1, 26.9, 26.3, 25.4; ESIHRMS Calcd for $\mathrm{C}_{32} \mathrm{H}_{40} \mathrm{NaO}_{10}[\mathrm{M}+\mathrm{Na}]^{+}: 607.2519$. Found 607.2524. 40ß. $[\alpha]^{24}{ }_{\mathrm{D}}-15.8\left(c 0.36, \mathrm{CHCl}_{3}\right) ;{ }^{1} \mathrm{H}$ NMR $\left(500 \mathrm{MHz}, \mathrm{CDCl}_{3}\right) \delta: 7.47-7.54(\mathrm{~m}$, $2 \mathrm{H}), 7.27-7.44(\mathrm{~m}, 8 \mathrm{H}), 5.92(\mathrm{~d}, J=3.7 \mathrm{~Hz}, 1 \mathrm{H}), 5.61(\mathrm{~s}, 1 \mathrm{H}), 4.83(\mathrm{~d}, J=12.1 \mathrm{~Hz}, 1 \mathrm{H}), 4.67$ $-4.73(\mathrm{~m}, 2 \mathrm{H}), 4.49(\mathrm{~d}, J=3.9 \mathrm{~Hz}, 1 \mathrm{H}), 4.28-4.38(\mathrm{~m}, 4 \mathrm{H}), 4.00-4.07(\mathrm{~m}, 2 \mathrm{H}), 3.82(\mathrm{t}, J$ $=10.3 \mathrm{~Hz}, 1 \mathrm{H}), 3.67-3.77(\mathrm{~m}, 2 \mathrm{H}), 3.34(\mathrm{td}, J=13.9,5.0 \mathrm{~Hz}, 1 \mathrm{H}), 2.26(\mathrm{ddd}, J=13.2,4.8$, $2.2 \mathrm{~Hz}, 1 \mathrm{H}), 1.69$ (ddd, $J=13.2,10.2 \mathrm{~Hz}, 1 \mathrm{H}), 1.50(\mathrm{~s}, 3 \mathrm{H}), 1.44(\mathrm{~s}, 3 \mathrm{H}), 1.38(\mathrm{~s}, 3 \mathrm{H}), 1.32$ (s, 3H); ${ }^{13} \mathrm{C}$ NMR $\left(125 \mathrm{MHz}, \mathrm{CDCl}_{3}\right) \delta: 138.4,137.4,129.0,128.4,128.3,127.7,126.0,111.9$, 108.5, 105.1, 101.3, 98.1, 82.84, 82.76, 80.3, 79.4, 74.2, 73.4, 72.6, 68.8, 66.8, 66.0, 37.5, 26.8, 26.6, 26.3, 25.5; ESIHRMS Calcd for $\mathrm{C}_{32} \mathrm{H}_{40} \mathrm{NaO}_{10}[\mathrm{M}+\mathrm{Na}]^{+}$: 607.2519. Found 607.2524. 
6-O-(3'-O-benzyl-4',6'-O-benzylidene-2'-deoxy- $\alpha$-o-arabino-thiohexopyranosyl)-1,2:3,4-di-Oisopropylidene- $\alpha-0-$ galactose $(41 \alpha)$ and 6-O-(3'-O-benzyl-4',6'-O-benzylidene-2'-deoxy- $\beta$ Darabino-thiohexopyranosyl)-1,2:3,4-di-O-isopropylidene- $\alpha$-o-galactose (41 $\beta$ )

Prepared by method A, purified by means of radial chromatography, eluting consecutive plates with hexanes to 3:17 ethyl acetate:hexanes, and then with 1:3 to 3:7 diethyl ether:hexanes. Combined yield $82 \mathrm{mg}(61 \%, 1: 4 \alpha / \beta) .41 \alpha .[\alpha]^{24}{ }_{\mathrm{D}}+16.9\left(c 0.14, \mathrm{CHCl}_{3}\right) ;{ }^{1} \mathrm{H} \mathrm{NMR}(400 \mathrm{MHz}$, $\left.\mathrm{CDCl}_{3}\right) \delta: 7.48-7.54(\mathrm{~m}, 2 \mathrm{H}), 7.23-7.41(\mathrm{~m}, 8 \mathrm{H}), 5.62(\mathrm{~s}, 1 \mathrm{H}), 5.53(\mathrm{~d}, J=5.3 \mathrm{~Hz}, 1 \mathrm{H})$, $4.97(\mathrm{~d}, J=3.5 \mathrm{~Hz}, 1 \mathrm{H}), 4.85(\mathrm{~d}, J=12.0 \mathrm{~Hz}, 1 \mathrm{H}), 4.68(\mathrm{~d}, J=12.0 \mathrm{~Hz}, 1 \mathrm{H}), 4.63(\mathrm{dd}, J=7.9$, $2.3 \mathrm{~Hz}, 1 \mathrm{H}), 4.32(\mathrm{dd}, J=5.0,2.3 \mathrm{~Hz}, 1 \mathrm{H}), 4.23-4.29(\mathrm{~m}, 2 \mathrm{H}), 4.05$ (ddd, $J=11.1,9.1,5.3$ $\mathrm{Hz}, 1 \mathrm{H}), 3.97(\mathrm{td}, J=6.6,1.8 \mathrm{~Hz}, 1 \mathrm{H}), 3.87(\mathrm{td}, J=9.9,4.7 \mathrm{~Hz}, 1 \mathrm{H}), 3.64-3.79(\mathrm{~m}, 4 \mathrm{H}), 2.32$ $(\mathrm{dd}, J=13.2,5.3 \mathrm{~Hz}, 1 \mathrm{H}), 1.80(\mathrm{ddd}, J=13.4,11.1,3.8 \mathrm{~Hz}, 1 \mathrm{H}), 1.55(\mathrm{~s}, 3 \mathrm{H}), 1.45(\mathrm{~s}, 3 \mathrm{H})$, $1.35(\mathrm{~s}, 3 \mathrm{H}), 1.34(\mathrm{~s}, 3 \mathrm{H}) ;{ }^{13} \mathrm{C}$ NMR $\left(100 \mathrm{MHz}, \mathrm{CDCl}_{3}\right) \delta: 138.8,137.6,128.9,128.3,128.2$, 127.6, 127.5, 126.1, 109.4, 108.6, 101.3, 98.1, 96.4, 83.9, 73.0, 71.0, 70.6, 69.1, 65.9, 65.8, 63.1, 36.5, 26.2, 26.0, 25.0, 24.6; FABHRMS Calcd for $\mathrm{C}_{32} \mathrm{H}_{40} \mathrm{NaO}_{10}[\mathrm{M}+\mathrm{Na}]^{+}: 607.2519$. Found 607.2515. 41ß. $[\alpha]^{24}{ }_{\mathrm{D}}-51.4\left(c 0.21, \mathrm{CHCl}_{3}\right) ;{ }^{1} \mathrm{H} \mathrm{NMR}\left(500 \mathrm{MHz}, \mathrm{CDCl}_{3}\right) \delta: 7.48-$ $7.53(\mathrm{~m}, 2 \mathrm{H}), 7.26-7.42(\mathrm{~m}, 8 \mathrm{H}), 5.59(\mathrm{~s}, 1 \mathrm{H}), 5.55(\mathrm{~d}, J=5.0 \mathrm{~Hz}, 1 \mathrm{H}), 4.79(\mathrm{~d}, J=12.3 \mathrm{~Hz}$, $1 \mathrm{H}), 4.71(\mathrm{~d}, J=12.1 \mathrm{~Hz}, 1 \mathrm{H}), 4.66(\mathrm{dd}, J=9.8,2.1 \mathrm{~Hz}, 1 \mathrm{H}), 4.60(\mathrm{dd}, J=8.0,2.5 \mathrm{~Hz}, 1 \mathrm{H})$, $4.29-4.34(\mathrm{~m}, 2 \mathrm{H}), 4.21(\mathrm{dd}, J=7.9,1.8 \mathrm{~Hz}, 1 \mathrm{H}), 3.97-4.05(\mathrm{~m}, 2 \mathrm{H}), 3.82(\mathrm{t}, J=10.3 \mathrm{~Hz}$, $1 \mathrm{H}), 3.64-3.77(\mathrm{~m}, 3 \mathrm{H}), 3.35(\mathrm{td}, J=9.6,5.0 \mathrm{~Hz}, 1 \mathrm{H}), 2.44(\mathrm{ddd}, J=13.0,5.0,2.1 \mathrm{~Hz}, 1 \mathrm{H})$, $1.69-1.78(\mathrm{~m}, 1 \mathrm{H}), 1.54(\mathrm{~s}, 3 \mathrm{H}), 1.45(\mathrm{~s}, 3 \mathrm{H}), 1.34(\mathrm{~s}, 3 \mathrm{H}), 1.31(\mathrm{~s}, 3 \mathrm{H}) ;{ }^{13} \mathrm{C}$ NMR $(125 \mathrm{MHz}$, $\mathrm{CDCl}_{3}$ ) $\delta:$ 138.7, 137.7 129.1, 128.6, 128.4, 127.9, 127.8, 126.3, 109.6, 108.9, 101.5, 101.3, 96.5, 83.2, 74.6, 72.5, 71.7, 70.9, 70.6, 69.4, 69.1, 68.0, 66.8, 37.7, 26.3, 26.2, 25.2, 24.6; ESIHRMS Calcd for $\mathrm{C}_{32} \mathrm{H}_{40} \mathrm{NaO}_{10}[\mathrm{M}+\mathrm{Na}]^{+}:$607.2519. Found 607.2521.

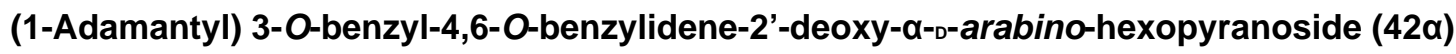
and (1-Adamantyl) 3-O-benzyl-4,6-O-benzylidene-2'-deoxy- $\beta$-o-arabino-hexopyranoside $(42 \beta)$

Prepared by method A, purified by means of radial chromatography, eluting consecutive plates with hexanes to 1:39 ethyl acetate:hexanes, and then with 1:9 diethyl ether:hexanes. Combined yield $33 \mathrm{mg}(30 \%, 1: 1.9 \alpha / \beta)$. 42 $\alpha$. White solid. M.p. $160-162{ }^{\circ} \mathrm{C} ;[\alpha]^{24} \mathrm{D}+54.7(c 0.086$, $\left.\mathrm{CHCl}_{3}\right) ;{ }^{1} \mathrm{H}$ NMR $\left(500 \mathrm{MHz}, \mathrm{CDCl}_{3}\right) \delta: 7.50-7.55(\mathrm{~m}, 2 \mathrm{H}), 7.22-7.42(\mathrm{~m}, 8 \mathrm{H}), 5.63(\mathrm{~s}$, $1 \mathrm{H}), 5.35(\mathrm{~d}, J=3.3 \mathrm{~Hz}, 1 \mathrm{H}), 4.87(\mathrm{~d}, J=11.7 \mathrm{~Hz}, 1 \mathrm{H}), 4.69(\mathrm{~d}, J=11.7 \mathrm{~Hz}, 1 \mathrm{H}), 4.22(\mathrm{dd}$, $J=10.3,5.0 \mathrm{~Hz}, 1 \mathrm{H}), 4.01-4.15(\mathrm{~m}, 2 \mathrm{H}), 3.73(\mathrm{t}, J=10.4 \mathrm{~Hz}, 1 \mathrm{H}), 3.67(\mathrm{t}, J=9.3 \mathrm{~Hz}, 1 \mathrm{H})$, $2.08-2.18(\mathrm{~m}, 4 \mathrm{H}), 1.73-1.86(\mathrm{~m}, 7 \mathrm{H}), 1.56-1.68(\mathrm{~m}, 6 \mathrm{H}) ;{ }^{13} \mathrm{C} \mathrm{NMR}\left(125 \mathrm{MHz}, \mathrm{CDCl}_{3}\right)$ $\delta: 139.0,137.8,128.8,128.3,128.2,127.6,127.5,126.0,101.2,91.2,84.4,74.2,73.4,73.0$, 69.2, 62.7, 42.5, 38.1, 36.3, 30.6; ESIHRMS Calcd for $\mathrm{C}_{30} \mathrm{H}_{36} \mathrm{NaO}_{5}[\mathrm{M}+\mathrm{Na}]^{+}$: 499.2461 . Found 499.2472. 42ß. Slightly yellow solid. M.p. 86-88 ${ }^{\circ} \mathrm{C} ;[\alpha]^{24}{ }_{\mathrm{D}}-11.5\left(c 0.19, \mathrm{CHCl}_{3}\right) ;{ }^{1} \mathrm{H}$ NMR (400 MHz, $\left.\mathrm{CDCl}_{3}\right)$ ): $7.47-7.55(\mathrm{~m}, 2 \mathrm{H}), 7.24-7.43(\mathrm{~m}, 8 \mathrm{H}), 5.59(\mathrm{~s}, 1 \mathrm{H}), 4.89(\mathrm{dd}$, $J=9.9,2.3 \mathrm{~Hz}, 1 \mathrm{H}), 4.80(\mathrm{~d}, J=12.0 \mathrm{~Hz}, 1 \mathrm{H}), 4.72(\mathrm{~d}, J=12.0 \mathrm{~Hz}, 1 \mathrm{H}), 4.27(\mathrm{dd}, J=10.5$, $5.0 \mathrm{~Hz}, 1 \mathrm{H}), 3.83(\mathrm{t}, J=10.4 \mathrm{~Hz}, 1 \mathrm{H}), 3.70-3.79(\mathrm{~m}, 1 \mathrm{H}), 3.67(\mathrm{t}, J=8.9 \mathrm{~Hz}, 1 \mathrm{H}), 3.35(\mathrm{td}$, $J=14.0,5.0 \mathrm{~Hz}, 1 \mathrm{H}), 2.11-2.22(\mathrm{~m}, 4 \mathrm{H}), 1.71-1.88(\mathrm{~m}, 7 \mathrm{H}), 1.56-1.70(\mathrm{~m}, 6 \mathrm{H}) ; 13 \mathrm{C}$ NMR (100 MHz, $\left.\mathrm{CDCl}_{3}\right) \delta: 138.6,137.6,128.9,128.4,128.2,127.63,127.56,126.1,101.3,93.1$, 82.9, 75.0, 74.9, 72.3, 69.1, 66.5, 42.5, 39.1, 36.2, 30.6; ESIHRMS Calcd for $\mathrm{C}_{30} \mathrm{H}_{36} \mathrm{NaO}_{5}[\mathrm{M}$ $+\mathrm{Na}]^{+}:$499.2461. Found 499.2452.

\section{Methyl 4-O-(2'-O-benzyl-4',6'-O-benzylidene-3'-deoxy- $\alpha$-o-ribo-thiohexopyranosyl)-2,3-O-

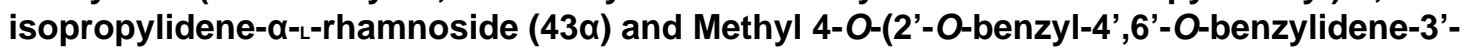 deoxy- $\beta$-o-ribo-thiohexopyranosyl)-2,3-O-isopropylidene- $\alpha$---rhamnoside (43 $\beta$ )}

Prepared by method B. Purified by means of radial chromatography, eluting with hexanes to 3:17 diethyl ether : hexanes to give $\mathbf{4 3 \alpha}(33 \mathrm{mg}, 53 \%)$ and $\mathbf{4 3 \beta}(26 \mathrm{mg}, 42 \%)$. 43a. White solid. M.p. $138-142{ }^{\circ} \mathrm{C} ;[\alpha]^{22} \mathrm{D}+31.1\left(c 0.074, \mathrm{CHCl}_{3}\right) ;{ }^{1} \mathrm{H} \mathrm{NMR}\left(500 \mathrm{MHz}, \mathrm{CDCl}_{3}\right) \delta: 7.48-7.52$ 
$(\mathrm{m}, 2 \mathrm{H}) 7.28-7.40(\mathrm{~m}, 8 \mathrm{H}), 5.50(\mathrm{~s}, 1 \mathrm{H}), 4.93(\mathrm{~d}, J=3.3 \mathrm{~Hz}, 1 \mathrm{H}), 4.86(\mathrm{~s}, 1 \mathrm{H}), 4.67(\mathrm{~d}, J=$ $12.1 \mathrm{~Hz}, 1 \mathrm{H}), 4.56(\mathrm{~d}, J=12.3 \mathrm{~Hz}, 1 \mathrm{H}), 4.21-4.28(\mathrm{~m}, 2 \mathrm{H}), 4.12(\mathrm{~d}, J=5.5 \mathrm{~Hz}, 1 \mathrm{H}), 4.06$ $(\mathrm{td}, J=9.8,5.0 \mathrm{~Hz}, 1 \mathrm{H}), 3.75-3.82(\mathrm{~m}, 1 \mathrm{H}), 3.57-3.67(\mathrm{~m}, 2 \mathrm{H}), 3.49(\mathrm{ddd}, J=11.6,9.5$, $4.0 \mathrm{~Hz}, 1 \mathrm{H}), 3.39$ (dd, $J=10.1,7.5 \mathrm{~Hz}, 1 \mathrm{H}), 3.36$ (s, 3H), 2.31 (ddd, $J=11.0,4.3,4.1 \mathrm{~Hz}, 1 \mathrm{H})$, $2.04\left(\mathrm{ddd}, J_{1}=J_{2}=J_{3}=11.7 \mathrm{~Hz}, 1 \mathrm{H}\right), 1.52(\mathrm{~s}, 3 \mathrm{H}), 1.37(\mathrm{~d}, J=6.2 \mathrm{~Hz}, 3 \mathrm{H}), 1.35(\mathrm{~s}$, $3 \mathrm{H}) ;{ }^{13} \mathrm{C} \mathrm{NMR}\left(125 \mathrm{MHz}, \mathrm{CDCl}_{3}\right) \delta: 137.8,137.5,129.1,128.5,128.4,127.9,127.7,126.3$, 109.1, 101.8, 97.9, 81.1, 76.1, 74.3, 71.1, 69.5, 64.9, 64.3, 54.7, 29.81, 29.75, 28.2, 26.5, 17.3; FABHRMS Calcd for $\mathrm{C}_{30} \mathrm{H}_{38} \mathrm{NaO}_{9}[\mathrm{M}+\mathrm{Na}]^{+}:$565.2414. Found 565.2390. 43及. $[\alpha]^{22}-43.9$ (c $\left.0.098, \mathrm{CHCl}_{3}\right) ;{ }^{1} \mathrm{H} \mathrm{NMR}\left(500 \mathrm{MHz}, \mathrm{CDCl}_{3}\right) \delta: 7.45-7.49(\mathrm{~m}, 2 \mathrm{H}), 7.27-7.39(\mathrm{~m}, 8 \mathrm{H})$, $5.49(\mathrm{~s}, 1 \mathrm{H}), 5.03(\mathrm{~d}, J=7.5 \mathrm{~Hz}, 1 \mathrm{H}), 4.87(\mathrm{~s}, 1 \mathrm{H}), 4.82(\mathrm{~d}, J=12.1 \mathrm{~Hz}, 1 \mathrm{H}), 4.65(\mathrm{~d}, J=12.1$ $\mathrm{Hz}, 1 \mathrm{H}), 4.23-4.29(\mathrm{~m}, 2 \mathrm{H}), 4.11(\mathrm{~d}, J=5.7 \mathrm{~Hz}, 1 \mathrm{H}), 3.63-3.76(\mathrm{~m}, 3 \mathrm{H}), 3.51$ (ddd, $J=$ $11.7,8.9,4.3 \mathrm{~Hz}, 1 \mathrm{H}), 3.31-3.43(\mathrm{~m}, 5 \mathrm{H}), 2.40(\mathrm{dt}, J=12.0,4.7 \mathrm{~Hz}, 1 \mathrm{H}), 1.79\left(\mathrm{ddd}, J_{1}=\right.$ $\left.J_{2}=J_{3}=11.7 \mathrm{~Hz}, 1 \mathrm{H}\right), 1.53(\mathrm{~s}, 3 \mathrm{H}), 1.36(\mathrm{~s}, 3 \mathrm{H}), 1.30(\mathrm{~d}, J=5.9 \mathrm{~Hz}, 3 \mathrm{H}) ;{ }^{13} \mathrm{C} \mathrm{NMR}(125$ $\left.\mathrm{MHz}, \mathrm{CDCl}_{3}\right) \delta: 138.6,137.4,129.1,128.4,127.7,127.6,126.2,109.3,103.1,101.7,98.1$, 78.2, 77.9, 77.6, 76.3, 76.0, 75.5, 72.8, 70.0, 69.3, 64.2, 55.0, 34.9, 27.9, 26.4, 17.7; FABHRMS Calcd for $\mathrm{C}_{30} \mathrm{H}_{38} \mathrm{NaO}_{9}[\mathrm{M}+\mathrm{Na}]^{+}:$565.2414. Found 565.2398.

\section{3-O-(2'-O-benzyl-4',6'-O-benzylidene-3'-deoxy- $\alpha$-o-ribo-thiohexopyranosyl)-1,2:5,6-di-O- isopropylidene- $\alpha$-o-glucose (44 $\alpha$ ) and 3-O-(2'-O-benzyl-4',6'-O-benzylidene-3'-deoxy- $\beta$-o- ribo-thiohexopyranosyl)-1,2:5,6-di- $O$-isopropylidene-- $\alpha$-o-glucose (44 $\beta)$}

Prepared by method B. Purified by means of radial chromatography, eluting with hexanes to 1:4 diethyl ether: hexanes, followed by normal phase HPLC, eluting with hexanes to 3:2 ethyl acetate: haxanes. Combined yield $51 \mathrm{mg}(76 \%, 4.7: 1 \alpha / \beta) .44 \alpha .[\alpha]^{22}{ }_{\mathrm{D}}+38.7(c 0.20$, $\left.\mathrm{CHCl}_{3}\right) ;{ }^{1} \mathrm{H} \mathrm{NMR}\left(400 \mathrm{MHz}, \mathrm{CDCl}_{3}\right) \delta: 7.45-7.52(\mathrm{~m}, 2 \mathrm{H}), 7.27-7.41(\mathrm{~m}, 8 \mathrm{H}), 5.96(\mathrm{~d}, J$ $=3.5 \mathrm{~Hz}, 1 \mathrm{H}), 5.52(\mathrm{~s}, 1 \mathrm{H}), 5.21(\mathrm{~d}, J=3.2 \mathrm{~Hz}, 1 \mathrm{H}), 4.60-4.67(\mathrm{~m}, 3 \mathrm{H}), 4.53(\mathrm{dt}, J=8.6,5.4$ $\mathrm{Hz}, 1 \mathrm{H}), 4.27-4.34(\mathrm{~m}, 2 \mathrm{H}), 4.10(\mathrm{dd}, J=8.5,2.6 \mathrm{~Hz}, 1 \mathrm{H}), 4.06(\mathrm{~d}, J=5.6 \mathrm{~Hz}, 2 \mathrm{H}), 3.75-$ $3.83(\mathrm{~m}, 1 \mathrm{H}), 3.70(\mathrm{t}, J=10.2 \mathrm{~Hz}, 1 \mathrm{H}), 3.61(\mathrm{ddd}, J=11.7,4.2,3.9 \mathrm{~Hz}, 1 \mathrm{H}), 3.49-3.57(\mathrm{~m}$, $1 \mathrm{H}), 2.29$ (ddd, $J=11.3,4.2,4.1 \mathrm{~Hz}, 1 \mathrm{H}), 2.04\left(\mathrm{ddd}, J_{1}=J_{2}=J_{3}=11.7 \mathrm{~Hz}, 1 \mathrm{H}\right), 1.51(\mathrm{~s}, 3 \mathrm{H})$, 1.43 (s, 3H), 1.33 (s, 3H), 1.28 (s, 3H); $\left.{ }^{13} \mathrm{C} \mathrm{NMR} \mathrm{(100} \mathrm{MHz,} \mathrm{CDCl}_{3}\right) \delta: 137.9,137.2,129.2$, $128.5,128.4,127.8,127.4,126.1,112.0,109.2$, 105.2, 101.7, 97.5, 84.1, 81.4, 80.1, 73.9, 72.1, 70.9, 69.3, 67.3, 65.0, 29.8, 27.1, 26.9, 26.4, 25.4; FABHRMS Calcd for $\mathrm{C}_{32} \mathrm{H}_{40} \mathrm{NaO}_{10}[\mathrm{M}$ $+\mathrm{Na}^{+}:$607.2519. Found 607.2524. 44及. $[\alpha]^{22}{ }_{\mathrm{D}}-50.0\left(c 0.042, \mathrm{CHCl}_{3}\right) ;{ }^{1} \mathrm{H} \mathrm{NMR}(500 \mathrm{MHz}$, $\left.\mathrm{CDCl}_{3}\right) \delta: 7.45-7.49(\mathrm{~m}, 2 \mathrm{H}), 7.28-7.40(\mathrm{~m}, 8 \mathrm{H}), 5.84(\mathrm{~d}, J=3.7 \mathrm{~Hz}, 1 \mathrm{H}), 5.49(\mathrm{~s}, 1 \mathrm{H})$, $4.66(\mathrm{~d}, J=11.7 \mathrm{~Hz}, 1 \mathrm{H}), 4.63(\mathrm{~d}, J=12.1 \mathrm{~Hz}, 1 \mathrm{H}), 4.54-4.58(\mathrm{~m}, 2 \mathrm{H}), 4.33-4.39(\mathrm{~m}, 3 \mathrm{H})$, $4.29(\mathrm{dd}, J=10.5,5.0 \mathrm{~Hz}, 1 \mathrm{H}), 4.04-4.09(\mathrm{~m}, 2 \mathrm{H}), 3.72(\mathrm{t}, J=10.3 \mathrm{~Hz}, 1 \mathrm{H}), 3.54(\mathrm{ddd}, J=$ $16.2,4.6,4.5 \mathrm{~Hz}, 1 \mathrm{H}), 3.31-3.43(\mathrm{~m}, 2 \mathrm{H}), 2.47(\mathrm{dt}, J=12.0,4.7 \mathrm{~Hz}, 1 \mathrm{H}), 1.75\left(\mathrm{ddd}, J_{1}=\right.$ $\left.J_{2}=J_{3}=11.9 \mathrm{~Hz}, 1 \mathrm{H}\right), 1.50(\mathrm{~s}, 3 \mathrm{H}), 1.45(\mathrm{~s}, 3 \mathrm{H}), 1.38(\mathrm{~s}, 3 \mathrm{H}), 1.28(\mathrm{~s}, 3 \mathrm{H}) ;{ }^{13} \mathrm{C} \mathrm{NMR}(125$ $\left.\mathrm{MHz}, \mathrm{CDCl}_{3}\right) \delta: 137.9,137.2,129.2,128.5,128.4,127.9,127.5,126.1,111.9,108.6,105.1$, $103.1,101.6,82.6,80.5,80.2,75.7,75.3,73.4,72.6,70.4,69.0,66.0,34.6,26.7,26.6,26.2$, 25.6; FABHRMS Calcd for $\mathrm{C}_{32} \mathrm{H}_{40} \mathrm{NaO}_{10}[\mathrm{M}+\mathrm{Na}]^{+}:$607.2519. Found 607.2509.

(1-Adamantyl) 2-O-benzyl-4,6-O-benzylidene-3-deoxy- $\alpha$-o-ribo-hexopyranoside (45 $\alpha$ ) and (1Adamantyl) 2-O-benzyl-4,6-O-benzylidene-3-deoxy- $\beta$-o-ribo-hexopyranoside (45 $\beta$ )

Prepared by method B. Purified by means of radial chromatography, eluting consecutive plates with hexanes to 1:19 diethyl ether:hexanes, and then with hexanes to 1:39 ethyl acetate:hexanes. Combined yield $50.4 \mathrm{mg}(92 \%, 1: 1.8 \alpha / \beta)$. 45a. White solid. M.p. 119-122 ${ }^{\circ} \mathrm{C} ;[\alpha]^{22}{ }_{\mathrm{D}}+43.6\left(c 0.078, \mathrm{CHCl}_{3}\right) ;{ }^{1} \mathrm{H} \mathrm{NMR}\left(400 \mathrm{MHz}, \mathrm{CDCl}_{3}\right) \delta: 7.45-7.53(\mathrm{~m}, 2 \mathrm{H}), 7.27$ $-7.43(\mathrm{~m}, 8 \mathrm{H}), 5.50(\mathrm{~s}, 1 \mathrm{H}), 5.28(\mathrm{~d}, J=3.5 \mathrm{~Hz}, 1 \mathrm{H}), 4.62(\mathrm{~d}, J=12.3 \mathrm{~Hz}, 1 \mathrm{H}), 4.58(\mathrm{~d}, J=$ $12.3 \mathrm{~Hz}, 1 \mathrm{H}), 4.20(\mathrm{dd}, J=10.2,4.7 \mathrm{~Hz}, 1 \mathrm{H}), 4.00(\mathrm{td}, J=9.9,4.8 \mathrm{~Hz}, 1 \mathrm{H}), 3.63(\mathrm{t}, J=10.4$ $\mathrm{Hz}, 1 \mathrm{H}), 3.53-3.59(\mathrm{~m}, 1 \mathrm{H}), 3.49$ (ddd, $J=11.4,9.4,4.4 \mathrm{~Hz}, 1 \mathrm{H}), 2.08-2.26(\mathrm{~m}, 5 \mathrm{H}), 1.82$ - $1.96(\mathrm{~m}, 6 \mathrm{H}), 1.59-1.70(\mathrm{~m}, 6 \mathrm{H}) ;{ }^{13} \mathrm{C} \mathrm{NMR}\left(100 \mathrm{MHz} \mathrm{CDCl}_{3}\right) \delta: 138.3,137.5,129.0$, 128.5, 128.3, 127.7, 127.6, 126.2, 101.7, 89.7, 74.5, 74.0, 70.6, 69.6, 63.7, 42.6, 36.3, 30.7, 
30.1; FABHRMS Calcd for $\mathrm{C}_{30} \mathrm{H}_{36} \mathrm{NaO}_{5}[\mathrm{M}+\mathrm{Na}]^{+}:$499.2461. Found 499.2447. 45及. $[\alpha]^{22_{\mathrm{D}}}$ $-19.2\left(\right.$ c $\left.0.052, \mathrm{CHCl}_{3}\right) ;{ }^{1} \mathrm{H} \mathrm{NMR}\left(500 \mathrm{MHz}, \mathrm{CDCl}_{3}\right) \delta: 7.43-7.51(\mathrm{~m}, 2 \mathrm{H}), 7.27-7.41(\mathrm{~m}$, $8 \mathrm{H}), 5.47(\mathrm{~s}, 1 \mathrm{H}), 4.85(\mathrm{~d}, J=12.1 \mathrm{~Hz}, 1 \mathrm{H}), 4.78(\mathrm{~d}, J=7.5 \mathrm{~Hz}, 1 \mathrm{H}), 4.68(\mathrm{~d}, J=12.1 \mathrm{~Hz}$, $1 \mathrm{H}), 4.26(\mathrm{dd}, J=10.5,5.0 \mathrm{~Hz}, 1 \mathrm{H}), 3.74(\mathrm{t}, J=10.3 \mathrm{~Hz}, 1 \mathrm{H}), 3.51(\mathrm{ddd}, J=11.7,8.9,4.3 \mathrm{~Hz}$, $1 \mathrm{H}), 3.35-3.44(\mathrm{~m}, 2 \mathrm{H}), 2.40(\mathrm{dt}, J=12.0,4.6 \mathrm{~Hz}, 1 \mathrm{H}), 2.15-2.22(\mathrm{~m}, 3 \mathrm{H}), 1.90-1.97(\mathrm{~m}$, $3 \mathrm{H}), 1.81-1.88(\mathrm{~m}, 3 \mathrm{H}), 1.76\left(\mathrm{ddd}, J_{1}=J_{2}=J_{3}=11.7 \mathrm{~Hz}, 1 \mathrm{H}\right), 1.60-1.71(\mathrm{~m}, 6 \mathrm{H}) ;{ }^{13} \mathrm{C}$ $\operatorname{NMR}\left(125 \mathrm{MHz}, \mathrm{CDCl}_{3}\right) \delta: 138.6,137.4,129.1,128.3,127.8,127.6,126.2,101.6,98.2,76.2$, 75.43, 75.37, 73.0, 70.0, 69.3, 42.8, 36.3, 35.3, 30.7; FABHRMS Calcd for $\mathrm{C}_{30} \mathrm{H}_{36} \mathrm{NaO}_{5}[\mathrm{M}$ $+\mathrm{Na}]^{+}:$499.2461. Found 499.2447.

\section{Methyl 4-O-(2'-O-benzyl-4',6'-O-benzylidene-3'-deoxy- $\alpha$-o-arabino-thiohexopyranosyl)-2,3- O-isopropylidene- $\alpha-$--rhamnoside (46a) and Methyl 4-O-(2'-O-benzyl-4',6'-O-benzylidene-3'- deoxy- $\beta$-o-arabino-thiohexopyranosyl)-2,3- $O$-isopropylidene- $\alpha$---rhamnoside (46 $\beta$ )}

Prepared by method B. Purified by means of radial chromatography, eluting with hexanes to 3:17 diethyl ether : hexanes. Combined yield $53.0 \mathrm{mg}(85 \%, 1.9: 1 \alpha / \beta)$. Analytical samples of both isomers were obtained by reverse phase HPLC separation, eluting with 1:1

water:acetonitrile to acetonitrile. 46a. White solid. M.p. $152-155^{\circ} \mathrm{C} ;[\alpha]^{22_{\mathrm{D}}}+54.6(c 0.108$, $\left.\mathrm{CHCl}_{3}\right) ;{ }^{1} \mathrm{H} \mathrm{NMR}\left(400 \mathrm{MHz}, \mathrm{CDCl}_{3}\right) \delta: 7.48-7.54(\mathrm{~m}, 2 \mathrm{H}), 7.27-7.41(\mathrm{~m}, 8 \mathrm{H}), 5.59(\mathrm{~s}$, $1 \mathrm{H}), 4.84(\mathrm{~s}, 1 \mathrm{H}), 4.79(\mathrm{~s}, 1 \mathrm{H}), 4.67(\mathrm{~d}, J=12.3 \mathrm{~Hz}, 1 \mathrm{H}), 4.56(\mathrm{~d}, J=12.3 \mathrm{~Hz}, 1 \mathrm{H}), 4.23$ (dd, $J=10.1,4.8 \mathrm{~Hz}, 1 \mathrm{H}), 4.06-4.15(\mathrm{~m}, 3 \mathrm{H}), 3.98-4.06(\mathrm{~m}, 1 \mathrm{H}), 3.78(\mathrm{t}, J=9.9 \mathrm{~Hz}, 1 \mathrm{H}), 3.65$ $-3.69(\mathrm{~m}, 1 \mathrm{H}), 3.54-3.63(\mathrm{~m}, 1 \mathrm{H}), 3.33-3.41(\mathrm{~m}, 4 \mathrm{H}), 2.23(\mathrm{dt}, J=13.1,3.3 \mathrm{~Hz}, 1 \mathrm{H}), 1.92$ $-2.01(\mathrm{~m}, 1 \mathrm{H}), 1.52(\mathrm{~s}, 3 \mathrm{H}), 1.34(\mathrm{~s}, 3 \mathrm{H}), 1.13(\mathrm{~d}, J=6.4 \mathrm{~Hz}, 3 \mathrm{H}) ;{ }^{13} \mathrm{C}$ NMR $(100 \mathrm{MHz}$, $\left.\mathrm{CDCl}_{3}\right) \delta: 137.8,137.7,129.0,128.5,128.3,127.9,127.8,126.2,109.2,102.0,98.5,98.0$ $\left({ }^{1} J_{\mathrm{CH}}=166.5\right), 80.3,76.9,76.0,74.6,74.2,71.3,69.4,65.1,64.8,54.8,29.3,28.2,26.5,17.3$; ESIHRMS Calcd for $\mathrm{C}_{30} \mathrm{H}_{39} \mathrm{O}_{9}[\mathrm{M}+\mathrm{H}]^{+}:$543.25886. Found 543.25986. 46及. White solid. M.p. $158-162{ }^{\circ} \mathrm{C} ;[\alpha]^{22}{ }_{\mathrm{D}}-67.1\left(\mathrm{c} 0.082, \mathrm{CHCl}_{3}\right) ;{ }^{1} \mathrm{H} \mathrm{NMR}\left(500 \mathrm{MHz}, \mathrm{CDCl}_{3}\right) \delta: 7.46-7.51(\mathrm{~m}$, $2 \mathrm{H}), 7.26-7.42(\mathrm{~m}, 8 \mathrm{H}), 5.56(\mathrm{~s}, 1 \mathrm{H}), 5.10(\mathrm{~d}, J=0.9 \mathrm{~Hz}, 1 \mathrm{H}), 4.88(\mathrm{~s}, 1 \mathrm{H}), 4.84(\mathrm{~d}, J=12.5$ $\mathrm{Hz}, 1 \mathrm{H}), 4.68(\mathrm{~d}, J=12.5 \mathrm{~Hz}, 1 \mathrm{H}), 4.25(\mathrm{dd}, J=10.5,5.0 \mathrm{~Hz}, 1 \mathrm{H}), 4.14-4.18(\mathrm{~m}, 1 \mathrm{H}), 4.10$ $(\mathrm{d}, J=5.5 \mathrm{~Hz}, 1 \mathrm{H}), 4.04(\mathrm{ddd}, J=11.8,9.2,4.5 \mathrm{~Hz}, 1 \mathrm{H}), 3.91(\mathrm{t}, J=10.4 \mathrm{~Hz}, 1 \mathrm{H}), 3.80-3.82$ (m, 1H), $3.63-3.73(\mathrm{~m}, 2 \mathrm{H}), 3.45(\mathrm{td}, J=9.7,4.9 \mathrm{~Hz}, 1 \mathrm{H}), 3.40(\mathrm{~s}, 3 \mathrm{H}), 2.31$ (dt, $J=13.1$, $3.9 \mathrm{~Hz}, 1 \mathrm{H}), 1.72-1.79(\mathrm{~m}, 1 \mathrm{H}), 1.54(\mathrm{~s}, 3 \mathrm{H}), 1.33-1.37(\mathrm{~m}, 6 \mathrm{H}) ;{ }^{13} \mathrm{C} \mathrm{NMR}(125 \mathrm{MHz}$, $\left.\mathrm{CDCl}_{3}\right) \delta: 138.7,137.6,129.0,128.32,128.28,127.7,127.6,126.1,109.3,101.9,100.9$

$\left({ }^{1} J_{\mathrm{CH}}=160.0\right), 97.9,78.5,77.7,76.1,74.6,74.1,73.3,71.2,69.1,64.3,54.9,33.9,27.9,26.5$, 17.7; FABHRMS Calcd for $\mathrm{C}_{30} \mathrm{H}_{38} \mathrm{NaO}_{9}[\mathrm{M}+\mathrm{Na}]^{+}: 565.2414$. Found 565.2408.

\section{3-O-(2'-O-benzyl-4',6'-O-benzylidene-3'-deoxy- $\alpha$-o-arabino-thiohexopyranosyl)-1,2:5,6-di-O- isopropylidene- $\alpha$-o-glucose (47 $\alpha$ ) and 3-O-(2'-O-benzyl-4',6'-O-benzylidene-3'-deoxy- $\beta$-o- arabino-thiohexopyranosyl)-1,2:5,6-di-O-isopropylidene- $\alpha$-o-glucose (47 $\beta$ )}

Prepared by method B. Purification by means of radial chromatography, eluting with hexanes to 1:3 diethyl ether : hexanes, gave crude products. Further purification of crude $\mathbf{4 7} \boldsymbol{\alpha}$ and $\mathbf{4 7} \boldsymbol{\beta}$ by means of normal phase HPLC, eluting with hexanes to 1:1 ethyl acetate : hexanes and hexanes to 3:2 ethyl acetate:hexanes respectively, afforded pure products $(53.5 \mathrm{mg}$, combined $80 \%$ yield, 1.3:1 $\alpha / \beta)$. 47 $\alpha$. White solid. M.p. $145-148{ }^{\circ} \mathrm{C} ;[\alpha]^{22}{ }_{\mathrm{D}}+37.6\left(c 0.492, \mathrm{CHCl}_{3}\right) ;{ }^{1} \mathrm{H}$ NMR (500 MHz, CDCl 3$) \delta: 7.48-7.52(\mathrm{~m}, 2 \mathrm{H}), 7.28-7.40(\mathrm{~m}, 8 \mathrm{H}), 5.88(\mathrm{~d}, J=3.5 \mathrm{~Hz}, 1 \mathrm{H})$, $5.61(\mathrm{~s}, 1 \mathrm{H}), 5.15(\mathrm{~s}, 1 \mathrm{H}), 4.64(\mathrm{~d}, J=12.3 \mathrm{~Hz}, 1 \mathrm{H}), 4.57-4.62(\mathrm{~m}, 2 \mathrm{H}), 4.34(\mathrm{~d}, J=2.4 \mathrm{~Hz}$, $1 \mathrm{H}), 4.28-4.31(\mathrm{~m}, 1 \mathrm{H}), 4.00-4.15(\mathrm{~m}, 5 \mathrm{H}), 3.81-3.89(\mathrm{~m}, 2 \mathrm{H}), 3.71-3.75(\mathrm{~m}, 1 \mathrm{H}), 2.24$ $(\mathrm{dt}, J=13.0,3.3 \mathrm{~Hz}, 1 \mathrm{H}), 1.96(\mathrm{td}, J=12.5,3.0 \mathrm{~Hz}, 1 \mathrm{H}), 1.51(\mathrm{~s}, 3 \mathrm{H}), 1.42(\mathrm{~s}, 3 \mathrm{H}), 1.33(\mathrm{~s}$, $6 \mathrm{H}) ;{ }^{13} \mathrm{C}$ NMR $\left(125 \mathrm{MHz}, \mathrm{CDCl}_{3}\right) \delta: 137.7,137.5,129.1,128.5,128.4,127.9,127.6,126.1$, $112.1,109.4,105.3,101.9,98.1\left({ }^{1} J_{\mathrm{CH}}=172.0\right), 84.1,81.5,79.9,74.5,74.1,72.5,71.3,69.3$, 67.9, 66.0, 29.4, 26.9, 26.3, 25.5; EIHRMS Calcd for $\mathrm{C}_{32} \mathrm{H}_{40} \mathrm{O}_{10}[\mathrm{M}]^{+}:$584.2622. Found 584.2659. 47ק. $[\alpha]^{22}{ }_{\mathrm{D}}-30.3\left(c 0.330, \mathrm{CHCl}_{3}\right) ;{ }^{1} \mathrm{H}$ NMR $\left(400 \mathrm{MHz}, \mathrm{CDCl}_{3}\right) \delta: 7.44-7.51$ $(\mathrm{m}, 2 \mathrm{H}), 7.27-7.40(\mathrm{~m}, 8 \mathrm{H}), 5.92(\mathrm{~d}, J=3.8 \mathrm{~Hz}, 1 \mathrm{H}), 5.56(\mathrm{~s}, 1 \mathrm{H}), 4.72(\mathrm{~d}, J=12.6 \mathrm{~Hz}, 1 \mathrm{H})$, 
$4.69(\mathrm{~s}, 1 \mathrm{H}), 4.64(\mathrm{~d}, J=12.6 \mathrm{~Hz}, 1 \mathrm{H}), 4.40-4.47(\mathrm{~m}, 2 \mathrm{H}), 4.33-4.38(\mathrm{~m}, 2 \mathrm{H}), 4.28(\mathrm{dd}, J$ $=10.4,4.8 \mathrm{~Hz}, 1 \mathrm{H}), 4.15-4.20(\mathrm{~m}, 1 \mathrm{H}), 4.02-4.11(\mathrm{~m}, 2 \mathrm{H}), 3.87(\mathrm{t}, J=10.4 \mathrm{~Hz}, 1 \mathrm{H}), 3.71$ $-3.75(\mathrm{~m}, 1 \mathrm{H}), 3.46(\mathrm{td}, J=9.6,5.0 \mathrm{~Hz}, 1 \mathrm{H}), 2.33(\mathrm{dt}, J=13.2,4.2 \mathrm{~Hz}, 1 \mathrm{H}), 1.68-1.78(\mathrm{~m}$, $1 \mathrm{H}), 1.51(\mathrm{~s}, 3 \mathrm{H}), 1.45(\mathrm{~s}, 3 \mathrm{H}), 1.36(\mathrm{~s}, 3 \mathrm{H}), 1.32(\mathrm{~s}, 3 \mathrm{H}) ;{ }^{13} \mathrm{C} \mathrm{NMR}\left(125 \mathrm{MHz}, \mathrm{CDCl}_{3}\right) \delta$ : $138.0,137.4,129.1,128.43,128.36,127.8,126.1,112.0,108.6,105.1,101.8,100.2\left({ }^{1} J_{\mathrm{CH}}=\right.$ 155.4), 82.7, 80.5, 80.2, 73.8, 73.6, 73.3, 72.6, 71.0, 69.0, 66.1, 32.8, 26.8, 26.6, 26.3, 25.5; EIHRMS Calcd for $\mathrm{C}_{32} \mathrm{H}_{40} \mathrm{O}_{10}[\mathrm{M}]^{+}:$584.2622. Found 584.2602.

(1-Adamantyl) 2-O-benzyl-4,6-O-benzylidene-3-deoxy- $\alpha$-o-arabino-hexopyranoside (48 $\alpha$ ) and (1-Adamantyl) 2-O-benzyl-4,6-O-benzylidene-3-deoxy- $\beta$-o-arabino-hexopyranoside (48 $\beta$ )

Prepared by method B. Purification by means of radial chromatography, eluting with hexanes to 1:19 ethyl acetate:hexanes, gave crude products. Further purification of crude $\mathbf{4 8 \alpha}$ and $\mathbf{4 8 \beta}$ by means of normal phase HPLC, eluting with hexanes to 3:2 ethyl acetate:hexanes,

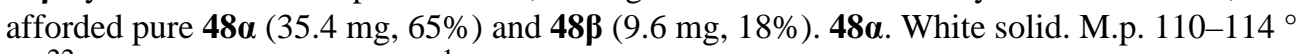
$\mathrm{C} ;{ }^{22}{ }_{\mathrm{D}}+61.9\left(c 0.690, \mathrm{CHCl}_{3}\right) ;{ }^{1} \mathrm{H}$ NMR $\left(500 \mathrm{MHz}, \mathrm{CDCl}_{3}\right) \delta: 7.49-7.53(\mathrm{~m}, 2 \mathrm{H}), 7.28-$ $7.41(\mathrm{~m}, 8 \mathrm{H}), 5.59(\mathrm{~s}, 1 \mathrm{H}), 5.15(\mathrm{~s}, 1 \mathrm{H}), 4.67(\mathrm{~d}, J=12.1 \mathrm{~Hz}, 1 \mathrm{H}), 4.59(\mathrm{~d}, J=12.1 \mathrm{~Hz}, 1 \mathrm{H})$, $4.19(\mathrm{dd}, J=10.3,4.8 \mathrm{~Hz}, 1 \mathrm{H}), 3.96-4.10(\mathrm{~m}, 2 \mathrm{H}), 3.78(\mathrm{t}, J=10.2 \mathrm{~Hz}, 1 \mathrm{H}), 3.54-3.57(\mathrm{~m}$, $1 \mathrm{H}), 2.21(\mathrm{dt}, J=12.8,3.5 \mathrm{~Hz}, 1 \mathrm{H}), 2.11-2.17(\mathrm{~m}, 3 \mathrm{H}), 2.06(\mathrm{td}, J=12.2,2.9 \mathrm{~Hz}, 1 \mathrm{H}), 1.74$ - $1.83(\mathrm{~m}, 6 \mathrm{H}), 1.57-1.68(\mathrm{~m}, 6 \mathrm{H}) ;{ }^{13} \mathrm{C} \mathrm{NMR}\left(125 \mathrm{MHz}, \mathrm{CDCl}_{3}\right) \delta: 138.1,137.8,129.0$, $128.5,128.3,127.8,127.7,126.2,101.9,91.0\left({ }^{1} J_{\mathrm{CH}}=166.5\right), 76.7,74.6,74.5,71.2,69.5,64.9$, 42.5, 36.3, 30.6, 29.2; FABHRMS Calcd for $\mathrm{C}_{30} \mathrm{H}_{36} \mathrm{NaO}_{5}[\mathrm{M}+\mathrm{Na}]^{+}:$499.2461. Found 499.2492. 48及. $[\alpha]^{22}{ }_{\mathrm{D}}-33.2\left(c 0.196, \mathrm{CHCl}_{3}\right) ;{ }^{1} \mathrm{H} \mathrm{NMR}\left(400 \mathrm{MHz}, \mathrm{CDCl}_{3}\right) \delta: 7.41-7.50$ $(\mathrm{m}, 4 \mathrm{H}), 7.25-7.40(\mathrm{~m}, 6 \mathrm{H}), 5.55(\mathrm{~s}, 1 \mathrm{H}), 4.88(\mathrm{~d}, J=13.1 \mathrm{~Hz}, 1 \mathrm{H}), 4.85(\mathrm{~d}, J=0.9 \mathrm{~Hz}, 1 \mathrm{H})$, $4.79(\mathrm{~d}, J=12.9 \mathrm{~Hz}, 1 \mathrm{H}), 4.24(\mathrm{dd}, J=10.4,4.8 \mathrm{~Hz}, 1 \mathrm{H}), 4.02(\mathrm{ddd}, J=11.8,9.2,4.4 \mathrm{~Hz}, 1 \mathrm{H})$, $3.88(\mathrm{t}, J=10.4 \mathrm{~Hz}, 1 \mathrm{H}), 3.57-3.62(\mathrm{~m}, 1 \mathrm{H}), 3.45(\mathrm{td}, J=9.6,5.0 \mathrm{~Hz}, 1 \mathrm{H}), 2.30(\mathrm{ddd}, J=$ 13.0, 3.8, 3.7 Hz, 1H), $2.14-2.20(\mathrm{~m}, 3 \mathrm{H}), 1.58-1.91(\mathrm{~m}, 13 \mathrm{H}) ;{ }^{13} \mathrm{C} \mathrm{NMR}(100 \mathrm{MHz}$, $\left.\mathrm{CDCl}_{3}\right) \delta: 138.8,137.7,129.0,128.3,128.2,127.9,127.4,126.2,101.9,95.3\left({ }^{1} J_{\mathrm{CH}}=152.6\right)$, 75.4, 74.9, 74.0, 73.0, 70.9, 69.3, 42.4, 36.3, 34.1, 30.6; FABHRMS Calcd for $\mathrm{C}_{30} \mathrm{H}_{36} \mathrm{NaO}_{5}$ $[\mathrm{M}+\mathrm{Na}]^{+}:$499.2461. Found 499.2413.

\section{Supplementary Material}

Refer to Web version on PubMed Central for supplementary material.

\section{Acknowledgment}

We thank Dr. Tom Hutton for helpful discussions and the NIH (GM 62160) for support of this work.

\section{References}

1. Crich D, Sun S. J. Org. Chem 1997;62:1198-1199.

2. Crich D, Sun S. Tetrahedron 1998;54:8321-8348.

3. Crich D, Sun S. J. Am. Chem. Soc 1998;120:435-436.

4. Crich D, Smith M. J. Am. Chem. Soc 2001;123:9015-9020. [PubMed: 11552809]

5. Crich D, Smith M. J. Am. Chem. Soc 2002;124:8867-8869. [PubMed: 12137540]

6. Crich D, de la Mora M, Vinod AU. J. Org. Chem 2003;68:8142-8148. [PubMed: 14535796]

7. Crich D, Cai W. J. Org. Chem 1999;64:4926-4930. [PubMed: 11674572]

8. Bousquet E, Khitri M, Lay L, Nicotra F, Panza L, Russo G. Carbohydr. Res 1998;311:171-181. [PubMed: 9825520]

9. Kim KS, Kang SS, Seo YS, Kim HJ, Jeong K-S. Synlett 2003:1311-1314.

10. Crich D, Smith M, Yao Q, Picione J. Synthesis 2001:323-326.

11. Crich D, Jayalath P. J. Org. Chem 2005;70:7252-7259. [PubMed: 16122245] 
12. Nukada T, Berces A, Whitfield DM. Carbohydr. Res 2002;337:765-774. [PubMed: 11950473]

13. Lemieux, RU. Molecular Rearrangements, Part 2. De Mayo, P., editor. New York: Wiley; 1964. p. 709-769.

14. Lucero CG, Woerpel KA. J. Org. Chem 2006;71:2641-2647. [PubMed: 16555815]

15. Smith DM, Woerpel KA. Org. Biomol. Chem 2006:1195-1201. [PubMed: 16557303]

16. Crich D, Sun S. J. Am. Chem. Soc 1997;119:11217-11223.

17. Crich D, Chandrasekera NS. Angew. Chem. Int. Ed 2004;43:5386-5389.

18. Fraser-Reid B, Wu ZC, Andrews W, Skowronski E. J. Am. Chem. Soc 1991;113:1434-1435.

19. Andrews CW, Rodebaugh R, Fraser-Reid B. J. Org. Chem 1996;61:5280-5289.

20. Jensen HH, Nordstrom M, Bols M. J. Am. Chem. Soc 2004;126:9205-9213. [PubMed: 15281809]

21. Lemieux RU, Hendriks KB, Stick RV, James K. J. Am. Chem. Soc 1975;97:4056-4062.

22. Torsion angles were determined with ring conformations fixed according to the parameters provided by Bérces and coworkers (http://www.nrc.ca/ibs/6ring.html)Bérces A, Whitfield DM, Nukuda T.

Tetrahedron 2001;57:477-491.

23. Edward JT. Chem. Ind 1955:1102-1104.

24. Feather MS, Harris JF. J. Org. Chem 1965;30:153-157.

25. Overend WG, Rees CW, Sequeira JS. J. Chem. Soc 1962:3429-3440.

26. Barton DHR, McCombie SW. J. Chem. Soc. Perkin Trans. 1 1975:1574-1585.

27. Withers SG, Percival MD, Street IP. Carbohydr. Res 1989;187:43-66.

28. Russell RN, Weigel TM, Han O, Liu H-w. Carbohydr. Res 1990;201:95-114. [PubMed: 2208194]

29. Classon B, Liu Z, Samuelsson B. J. Org. Chem 1988;53:6126-6130.

30. Theander O. Acta Chem. Scand 1958;12:1883-1885.

31. Barresi, F.; Hindsgaul, O. Modern Methods in Carbohydrate Synthesis. Khan, SH.; O'Neill, RA., editors. Amsterdam: Harwood Academic Publishers; 1996. p. 251-276.

32. Pozsgay, V. Carbohydrates in Chemistry and Biology. Ernst, B.; Hart, GW.; Sinaÿ, P., editors. Vol. 1. Weinheim: Wiley-VCH; 2000. p. 319-343.

33. Ito, Y.; Ohnishi, Y. Glycoscience: Chemistry and Chemical Biology. Fraser-Reid, B.; Kuniaki, T.; Thiem, J., editors. Vol. 2. Berlin: Springer-Verlag: 2001. p. 1589-1619.

34. Lichtenthaler, Fw; Lergenmüller, M.; Peters, S.; Varga, Z. Tetrahedron: Asym 2003;14:727-736.

35. Ekborg G, Lindberg B, Lonngren J. Acta Chem. Scand. B 1972;26:3287-3292.

36. Dess PB, Martin JC. J. Org. Chem 1983;48:4155-4156.

37. Roush WR, Sebesta DP, Bennett CE. Tetrahedron 1997;53:8825-8836.

38. Crich D, Ritchie TJ. J. Chem. Soc., Perkin Trans. 1 1990:945-954.

39. Codée JDC, van den Bos LJ, Litjens REJN, Overkleeft HS, van Boeckel CAA, van Boom JH, van der Marel GA. Tetrahedron 2004;60:1057-1064.

40. Codée JDC, Litjens REJN, Van den Bos LJ, Overkleeft HS, Van der Marel G. Chem. Soc. Rev 2005;34:769-782. [PubMed: 16100617]

41. Garcia BA, Gin DY. J. Am. Chem. Soc 2000;122:4269-4279.

42. Crich D, Hutton TK, Banerjee A, Jayalath P, Picione J. Tetrahedron: Asym 2005;16:105-119.

43. Bock K, Pedersen C. J. Chem. Soc., Perkin Trans. 2 1974:293-297.

44. Duus JO, Gotfredsen CH, Bock K. Chem. Rev 2000;100:4589-4614. [PubMed: 11749359]

45. Thiem J, Klaffke W. Topics Curr. Chem 1990;154:285-332.

46. Marzabadi CH, Franck RW. Tetrahedron 2000;56:8385-8417.

47. Veyrières, A. Carbohydrates in Chemistry and Biology. Ernst, B.; Hart, GW.; Sinaÿ, P., editors. Vol. 13. Weinheim: Wiley-VCH; 2000. p. 367-405.

48. Green, LG.; Ley, SV. Carbohydrates in Chemistry and Biology. Ernst, B.; Hart, GW.; Sinaÿ, P., editors. Vol. 1. Weinheim: Wiley-VCH; 2000. p. 427-448.

49. Zhang Z, Ollmann IR, Ye X-S, Wischnat R, Baasov T, Wong C-H. J. Am. Chem. Soc 1999;121:734753. 
50. Namchuk MN, McCarter JD, Becalski A, Andrews T, Withers SG. J. Am. Chem. Soc 2000;122:1270_ 1277.

51. Raghavan S, Kahne D. J. Am. Chem. Soc 1993;115:1580-1581.

52. Gildersleeve J, Smith A, Sakurai D, Raghavan S, Kahne D. J. Am. Chem. Soc 1999;121:6176-6182.

53. Hashimoto S, Sano A, Sakamoto H, Nakajima M, Yanagiya Y, Ikegami S. Synlett 1995:1271-1273.

54. Bock K, Pedersen H. Acta Chem. Scand 1987;B41:617-628.

55. van Dorst JALM, van Heusden CJ, Tikkanen JM, Kamerling JP, Vliegenthart JFG. Carbohydr. Res 1997;297:209-227. [PubMed: 9060187]

56. Oscarson S, Svahnberg P. Carbohydr. Res 1998;309:207-212. [PubMed: 9741077]

57. Oscarson S, Tedebark U. Carbohydr. Res 1995;278:271-287. [PubMed: 8590445]

58. Kováač P, Edgar KJ. Carbohydr. Res 1990;201:79-83. [PubMed: 2208193]

59. Richards GN. Chem. Ind 1955:228-228.

60. Crich D, Cai W, Dai Z. J. Org. Chem 2000;65:1291-1297. [PubMed: 10814088]

61. Crich D, Vinod AU, Picione J, Wink DJ. ARKIVOC 2005;(vi):339-344. [PubMed: 18490964]

62. Crich D, Vinod AU, Picione J. J. Org. Chem 2003;68:8453-8458. [PubMed: 14575470] 


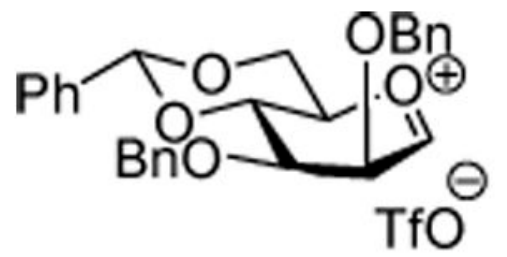

mannose

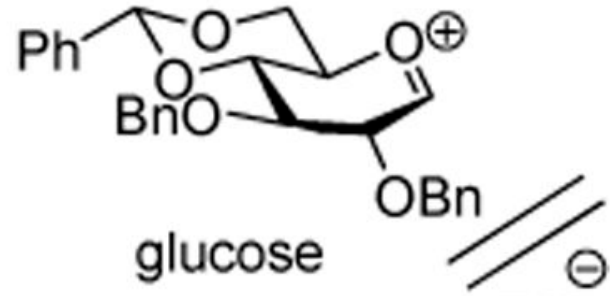

$\mathrm{TfO}$

Figure 1.

Destabilizing Interaction in the Contact Ion Pair, Illustrated for the 4,6-O-Benzylidene Protected Glucosyl Triflates. 


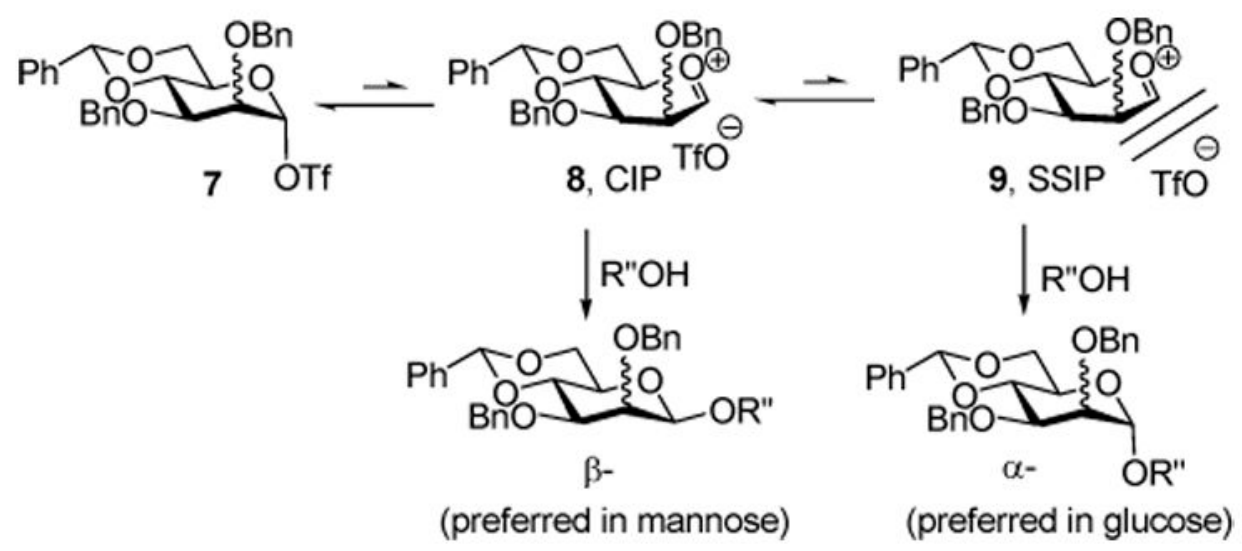

Scheme 1.

The Glycosylation Mechanism 


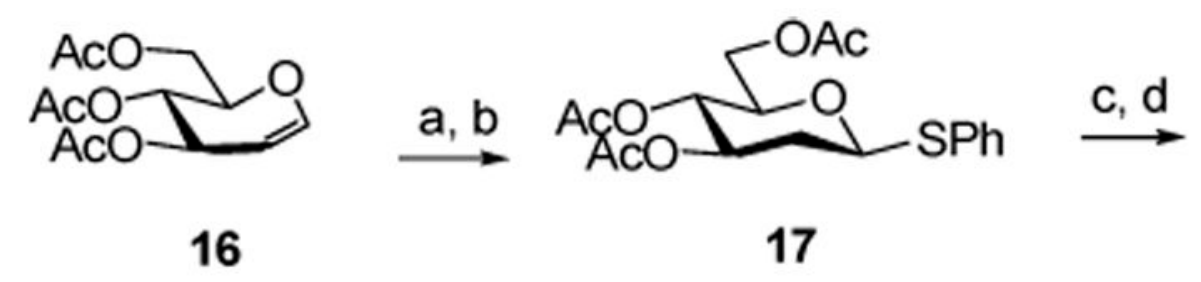

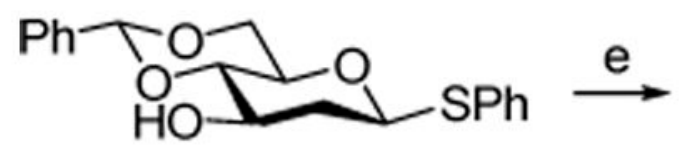

18

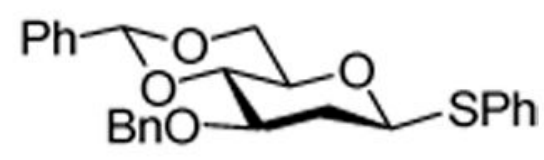

19

Scheme 2. Synthesis of the 2-Deoxy donor 19

Reagents and conditions: a) $\mathrm{HCl}$, toluene, $0{ }^{\circ} \mathrm{C}$; b) $\mathrm{PhSH},(i \text {-Pr })_{2} \mathrm{EtN}$, toluene, r.t., $47 \%$ over two steps; c) $\mathrm{NaOMe}, \mathrm{MeOH}$; d) $\mathrm{PhCH}(\mathrm{OMe})_{2}, p$-TsOH, DMF, $50{ }^{\circ} \mathrm{C}, 60 \%$ over two steps; e) $\mathrm{NaH}, \mathrm{BnBr}, \mathrm{THF}$, reflux, $73 \%$. 


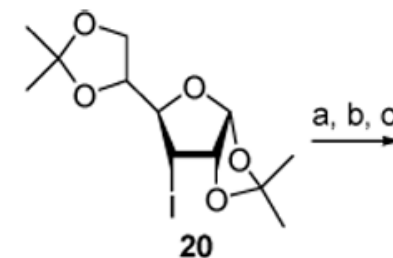

20

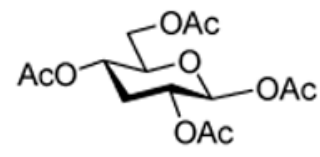

21

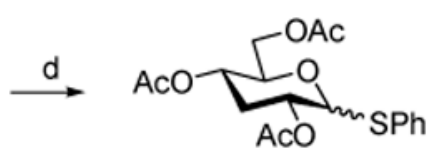

22: $\beta$

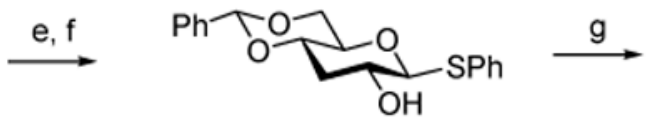

24

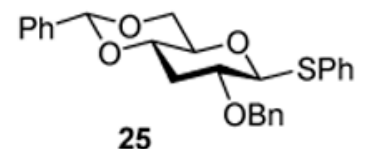

Scheme 3. Preparation of the 3-Deoxy ribo Donor 25

Reagents and conditions: a) IR-120 $\left(\mathrm{H}^{+}\right), \mathrm{H}_{2} \mathrm{O}, 80^{\circ} \mathrm{C}$; b) $\mathrm{Ac}_{2} \mathrm{O}$, Pyridine, DMAP, r.t., $85 \%$ for two steps; c) $\mathrm{Bu}_{3} \mathrm{SnH}$, AIBN, toluene, reflux, 78\%; d) $\mathrm{PhSH}, \mathrm{BF}_{3} \cdot \mathrm{Et}_{2} \mathrm{O}, \mathrm{DCM}, 0{ }^{\circ} \mathrm{C}, 97 \%$, $\alpha: \beta=1: 4$; e) $\mathrm{NaOMe}, \mathrm{MeOH} ; \mathrm{f}) \mathrm{PhCH}(\mathrm{OMe})_{2}, p$-TsOH, DMF, $50{ }^{\circ} \mathrm{C}, 96 \%$ for two steps; $\mathrm{g}$ ) $\mathrm{NaH}, \mathrm{BnBr}, \mathrm{THF}$, reflux, $93 \%$. 


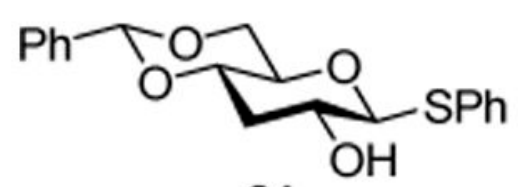

24

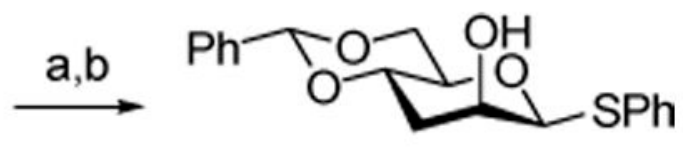

26

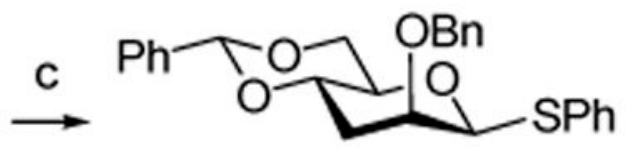

27

Scheme 4. Preparation of the 3-Deoxy arabino Donor 27

Reagents and conditions: a) Dess-Martin periodinane, DCM, r.t.; b) L-selectride, THF, $-78^{\circ}$ C, $81 \%$ for two steps; c) $\mathrm{NaH}, \mathrm{BnBr}$, THF, reflux, $94 \%$. 
Table 1

Torsional angle values for mannosyl triflate (10), and the ${ }^{4} H_{3}(\mathbf{1 1})$ and $B_{2,5}(\mathbf{1 2})$ conformers of mannosyl cation. ${ }^{22}$

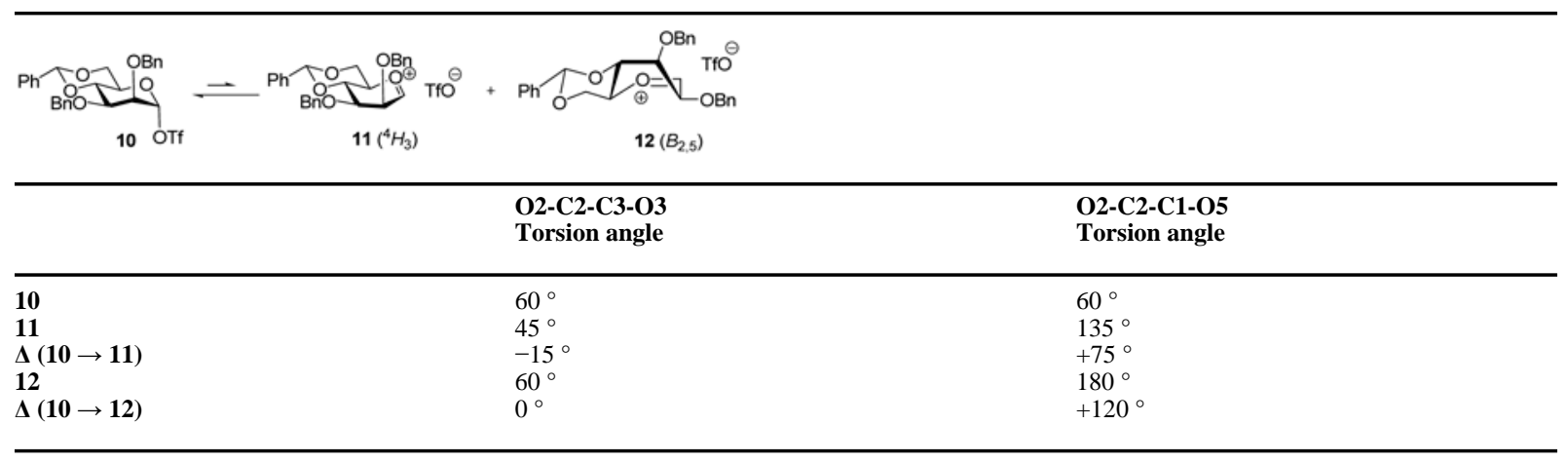


Table 2

Torsional angle values for glucosyl triflate (13), and the ${ }^{4} H_{3}(\mathbf{1 4})$ and ${ }^{4} E(\mathbf{1 5})$ conformers of glucosyl cation.

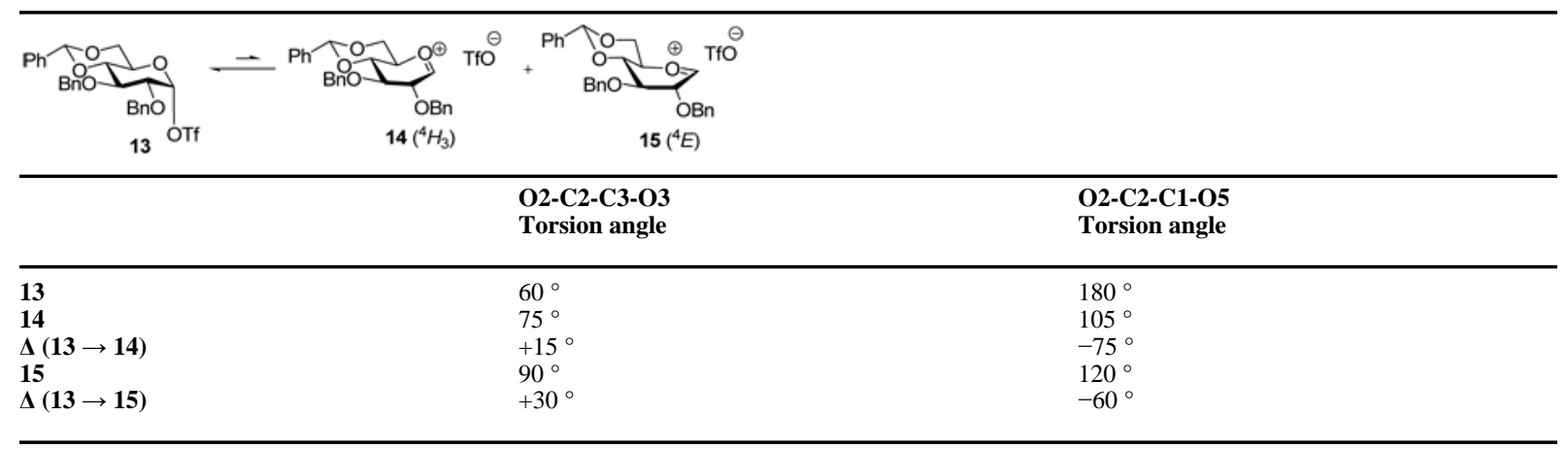


Table 3

Glycosylation of the 2-Deoxy Donor 19.

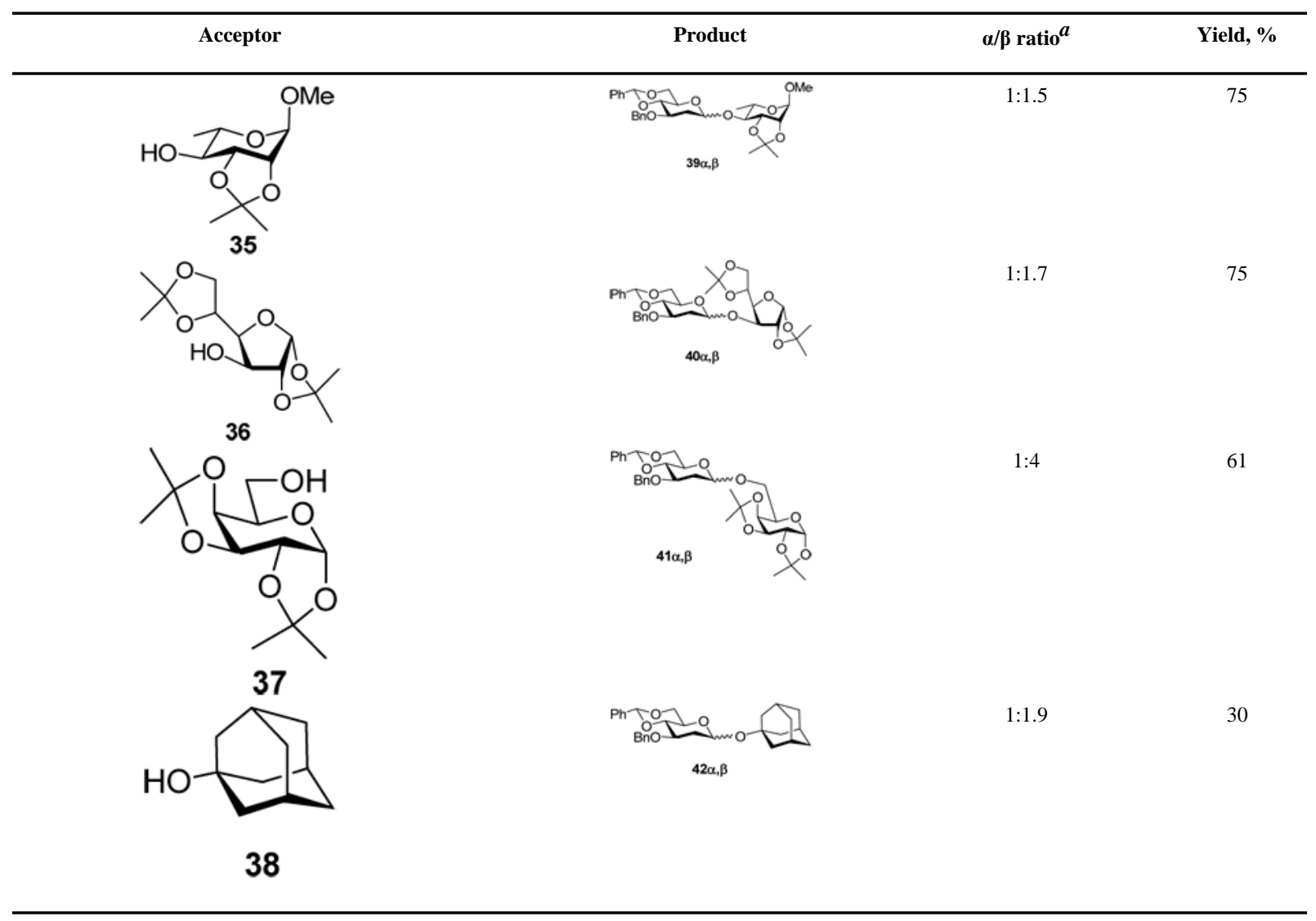

$a_{\text {determined by }}{ }^{1} \mathrm{H}-\mathrm{NMR}$ spectroscopy on the reaction mixture. 
Table 4

Glycosylation of the 3-Deoxy Donor 25.

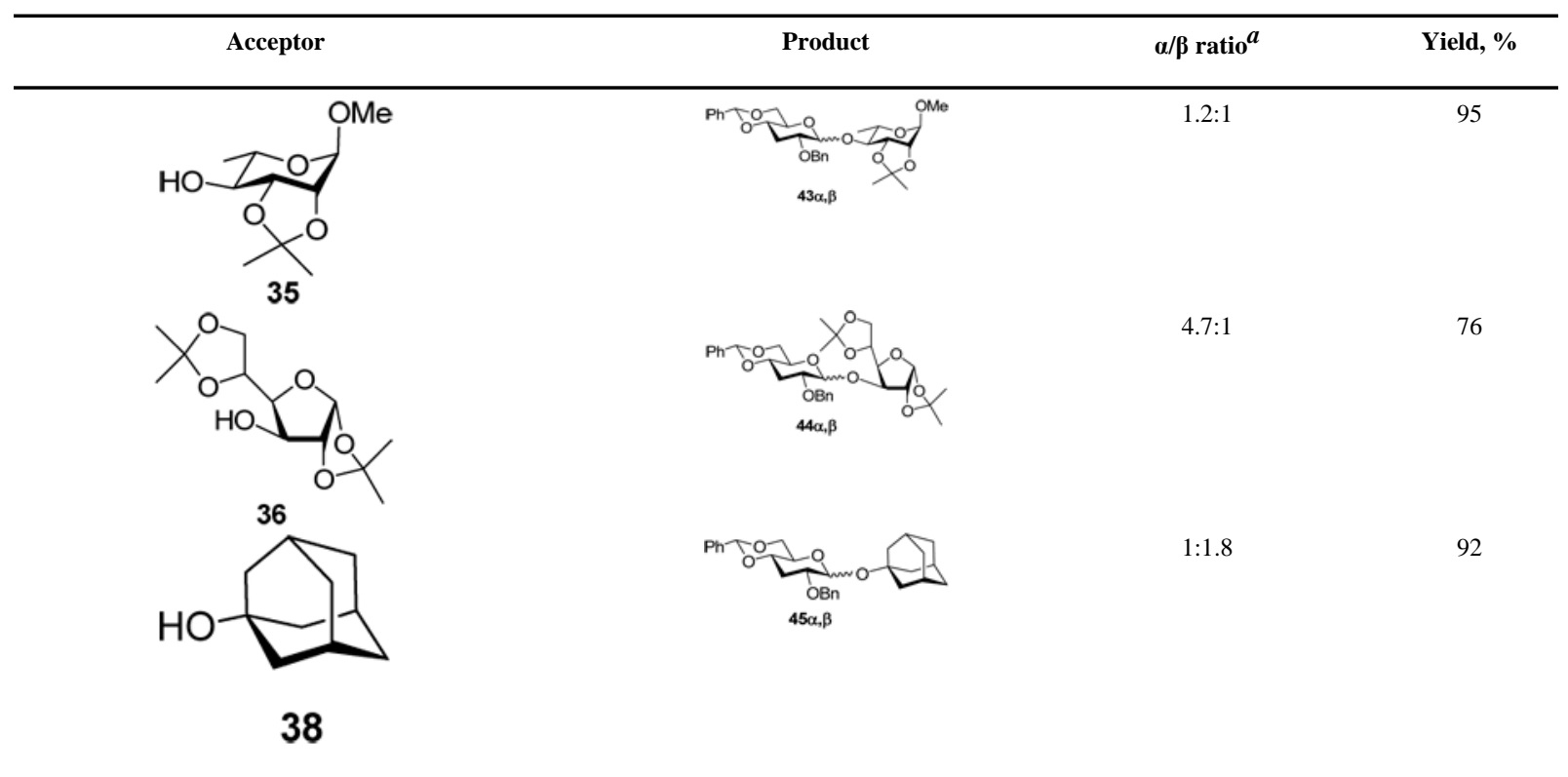

$a_{\text {determined by }}{ }^{1} \mathrm{H}-\mathrm{NMR}$ spectroscopy on the reaction mixture. 
Table 5

Glycosylation of the 3-Deoxy Donor 27.

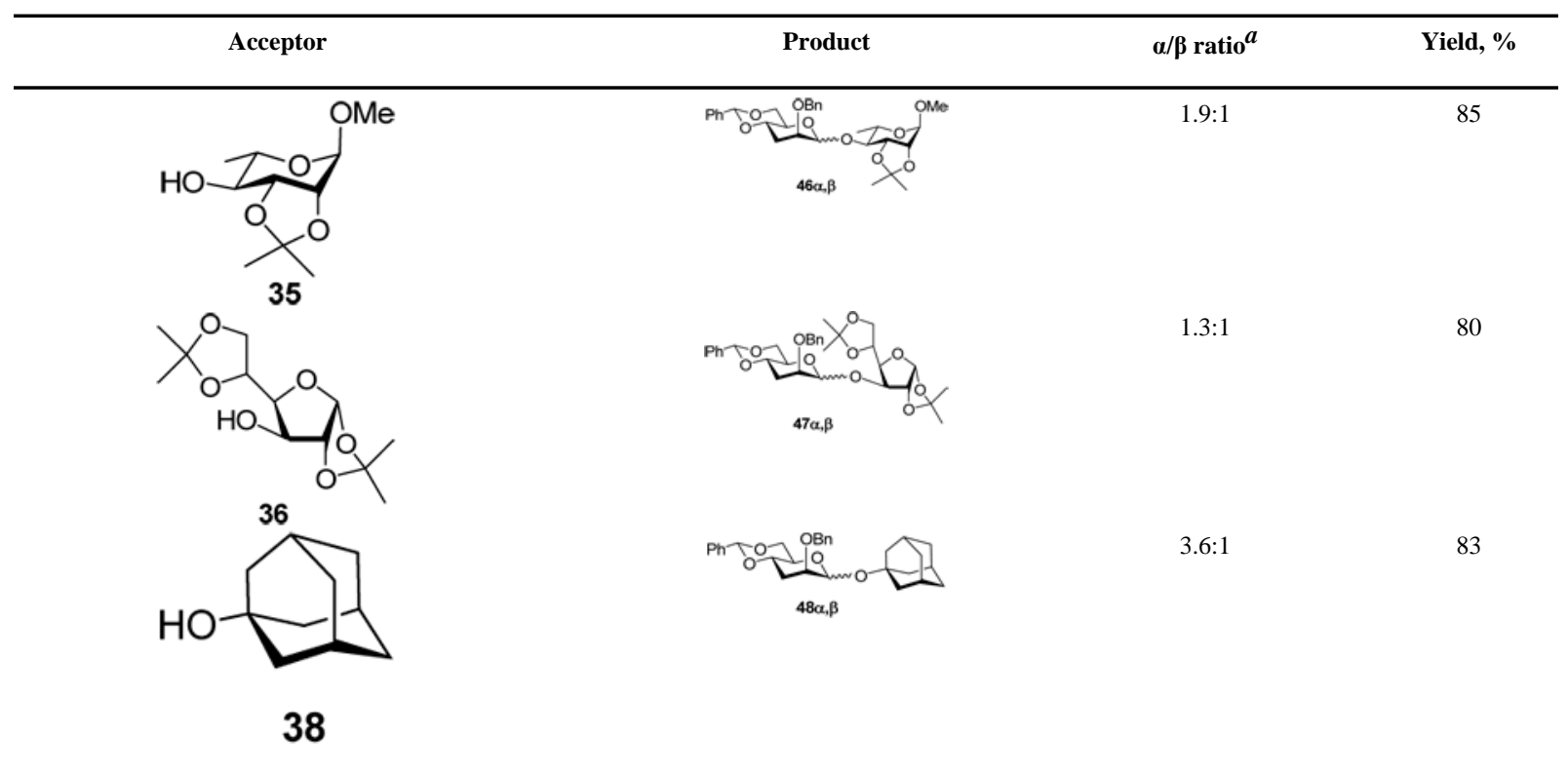

$a_{\text {determined by }}{ }^{1} \mathrm{H}-\mathrm{NMR}$ spectroscopy on the reaction mixture. 